\title{
The Power of the Pill: Oral Contraceptives and Women's Career and Marriage Decisions
}

\section{Citation}

Goldin, Claudia and Lawrence F. Katz. 2002. The power of the pill: Oral contraceptives and women's career and marriage decisions. Journal of Political Economy 110(4): 730-770.

\section{Published Version}

http://dx.doi.org/10.1086/340778

\section{Permanent link}

http://nrs.harvard.edu/urn-3:HUL.InstRepos:2624453

\section{Terms of Use}

This article was downloaded from Harvard University's DASH repository, and is made available under the terms and conditions applicable to Other Posted Material, as set forth at http:// nrs.harvard.edu/urn-3:HUL.InstRepos:dash.current.terms-of-use\#LAA

\section{Share Your Story}

The Harvard community has made this article openly available.

Please share how this access benefits you. Submit a story.

Accessibility 


\title{
The Power of the Pill: Oral Contraceptives and Women's Career and Marriage Decisions
}

\section{Claudia Goldin and Lawrence F. Katz}

Harvard University and National Bureau of Economic Research

\begin{abstract}
The fraction of U.S. college graduate women entering professional programs increased substantially just after 1970, and the age at first marriage among all U.S. college graduate women began to soar around the same year. We explore the relationship between these two changes and the diffusion of the birth control pill ("the pill") among young, unmarried college graduate women. Although the pill was approved in 1960 by the Food and Drug Administration and spread rapidly among married women, it did not diffuse among young, single women until the late 1960s after state law changes reduced the age of majority and extended "mature minor" decisions. We present both descriptive time series and formal econometric evidence that exploit cross-state and cross-cohort variation in pill availability to young, unmarried women, establishing the "power of the pill" in lowering the costs of long-duration professional education for women and raising the age at first marriage.
\end{abstract}

The careers of college graduate women and their age at first marriage both changed significantly in the United States with cohorts born around 1950. Women were 10 percent of first-year law students in 1970

We have benefited from conversations and communications with Joshua Angrist, John Bound, Judith Chevalier, Edward Glaeser, Michael Kremer, David Laibson, David I. Levine, Steven Levitt, Rhona Mahony, Ellen Meara, Casey Mulligan, Alvin Roth, Kathryn Shaw, and Andrei Shleifer and from seminar participants at University of California at Berkeley, University of Chicago, Harvard, Massachusetts Institute of Technology, University of Michigan, NBER, Ohio State University, Uppsala University, and University of Wisconsin. John Donohue and Steven Levitt generously provided the abortion data. An earlier version was improved by the comments of two anonymous referees. For research assistance we thank Anne Berry and, especially, Tara Watson and acknowledge the Spencer Foundation in providing that funding.

[Journal of Political Economy, 2002, vol. 110, no. 4]

(C) 2002 by The University of Chicago. All rights reserved. 0022-3808/2002/11004-0004\$10.00 
but were 36 percent in 1980. Among the cohort of female college graduates born in 1950, almost 50 percent married before age 23, but fewer than 30 percent did for those born in 1957. We ask whether the birth control pill and the legal environment that enabled young, unmarried women to obtain "the pill" altered women's career plans and their age at first marriage. Our answer is that they did.

The pill directly lowered the costs of engaging in long-term career investments by giving women far greater certainty regarding the pregnancy consequences of sex. In the absence of an almost infallible contraceptive method, young women embarking on a lengthy professional education would have to pay the penalty of abstinence or cope with considerable uncertainty regarding pregnancy. ${ }^{1}$ The pill had an indirect effect, as well, by reducing the marriage market cost to women who delayed marriage to pursue a career. With the advent of the pill, all individuals could delay marriage and not pay as large a penalty. The pill, by encouraging the delay of marriage, created a "thicker" marriage market for career women. Thus the pill may have enabled more women to opt for careers by indirectly lowering the cost of career investment.

Our empirical argument relies on the timing of various changes and on formal econometric analyses of the age at first marriage and career change by taking advantage of the differential effect of legal changes by cohort and state. Legal changes by states lowered the age of majority and expanded the rights of minors in the late 1960s and early 1970s and, by doing so, facilitated the diffusion of the pill among young, single women.

The first issue we explore is the diffusion of the pill among single women and the legal reasons for its delayed dissemination. We then formally model the potential effects of the pill on marriage and career. Next, we use cross-section data for 1971 to establish that the timing of the pill's diffusion among young, unmarried women was, at least in part, caused by legal changes in the age of majority and mature minor statutes. We then present both descriptive time series and formal econometric evidence showing the relationship between pill use, on the one hand, and the age at first marriage and career investment, on the other. Alternative explanations, including legalization of abortion, feminism, and antidiscrimination laws, are considered.

\footnotetext{
${ }^{1}$ Contraceptive methods are rated by the probability of a pregnancy per year occurring to the average woman (or couple) who uses the method "perfectly" and who uses it "typically" (Kelly 1998). The oral contraceptive (with estrogen and progestin) has a rating of 0.1 percent and 3 percent, respectively, the diaphragm (used with a spermicide) has a rating of 6 percent and 20 percent, and the condom is rated 3 percent and 12 percent. In comparison with the pill, therefore, the diaphragm is 60 times more risky in perfect use and seven times typically, whereas the condom is 30 times more risky when perfectly used and four times in typical use.
} 


\section{The Pill and Single Women}

\section{A. Diffusion of the Pill among Single Women}

In 1960 the Food and Drug Administration (FDA) approved the use of norethynodrel, a synthetic progesterone, as an oral contraceptive for women. ${ }^{2}$ The product was christened Enovid by its manufacturer, but nearly everyone else called it and its successors "the pill." Oral contraceptives-also known as "the pill"-remain among the greatest miracle drugs. ${ }^{3}$ (See table 1 for the history of the birth control pill and landmark decisions regarding contraception.)

The pill diffused rapidly among married women in the United States. By 1965, only five years after its release, 41 percent of "contracepting" married women younger than 30 years were "on the pill" (Westoff and Ryder 1977, table II-3). ${ }^{4}$ The fraction of married women using the pill peaked around 1967, but it was then only just beginning to be used by young, single women.

Both legal and social factors were responsible for the delayed dissemination of the pill among unmarried women. ${ }^{5}$ Until the late 1960s, single women who were below the age of majority and did not have parental consent were often denied access to the pill and other forms of contraception. ${ }^{6}$ Before the late 1960s, it was not legal in any state for a physician to prescribe an oral contraceptive to an unmarried minor without consent of her parents. ${ }^{7}$ But by 1972 , on the heels of the Twentysixth Amendment (1971), the "age of majority" had been lowered to 18 years old in most states. Beginning in the late 1960s, "mature minors" in many states were enabled, by judicial decision and statute, to obtain contraceptive services. The extension of family planning services to minors and changes in community norms were reinforcing.

\footnotetext{
${ }^{2}$ A closely related drug, norethindrone, had already been approved for medical uses, not contraception, two years before. On the history of the pill, see Asbell (1995) and Watkins (1998).

${ }^{3}$ The Economist ("Oral Contraceptives: The Liberator," 1999) named the pill the greatest advance in science and technology in the twentieth century.

${ }^{4}$ This figure includes only couples using any form of contraception, including sterilization, rhythm, and withdrawal. Of all married women younger than 30 years old, 26 percent were on the pill in 1965 , but many who did not use contraceptives were trying to get pregnant, were pregnant, or recently had a baby.

${ }^{5}$ The fraction of all women who ever used the pill reached a peak of 85 percent with the cohort born in 1948 and then declined to around 80 percent (calculated from the 1987 National Health Interview Survey [Inter-university Consortium for Political and Social Research 1990]).

${ }^{6}$ Massachusetts and Wisconsin even had legislative proscriptions against the sale of contraceptive devices to any unmarried individual. Not until 1972 was the Massachusetts law overturned by the U.S. Supreme Court in Eisenstadt v. Baird.

${ }^{7}$ No record exists of a doctor's successful prosecution under a criminal statute regarding provision of contraceptive services to minors (U.S. Department of Health, Education, and Welfare 1974, p. 70).
} 
TABLE 1

Landmark Events and Decisions Regarding the Pill and Contraceptive Use

\begin{tabular}{|c|c|}
\hline Year & Event or Landmark Decision \\
\hline 1873 & $\begin{array}{l}\text { Congressional passage of the Act for the Suppression of Trade in, and Circu- } \\
\text { lation of Obscene Literature and Articles of Immoral Use, also known as } \\
\text { the "Comstock Law" }\end{array}$ \\
\hline 1916 & $\begin{array}{l}\text { In direct violation of state law, Margaret Sanger opens the first birth control } \\
\text { clinic in the United States }\end{array}$ \\
\hline 1936 & $\begin{array}{l}\text { U.S. Circuit Court of Appeals modifies the Comstock Law to allow the dis- } \\
\text { semination of birth control information and devices }\end{array}$ \\
\hline 1937 & Researchers discover the function of progesterone in inhibiting ovulation \\
\hline 1949 & $\begin{array}{l}\text { Russell Marker synthesizes inexpensive cortisone for the treatment of rheu- } \\
\text { matoid arthritis }\end{array}$ \\
\hline 1950 & $\begin{array}{l}\text { Margaret Sanger convinces the heiress Katherine Dexter McCormick to fund } \\
\text { research on "the pill" }\end{array}$ \\
\hline 1951 & $\begin{array}{l}\text { Carl Djerassi at Syntex synthesizes norethindrone, an orally active progesta- } \\
\text { tional hormone }\end{array}$ \\
\hline 1952 & $\begin{array}{l}\text { Chemist Frank Colton at G. D. Searle develops norethynodrel, chemically } \\
\text { similar to norethindrone }\end{array}$ \\
\hline 1953 & $\begin{array}{l}\text { Katherine Dexter McCormick promises Gregory Pincus (researcher and } \\
\text { Searle consultant) to fund his project to develop a birth control pill } \\
\text { through its completion }\end{array}$ \\
\hline 1954 & $\begin{array}{l}\text { Researchers John Rock and Gregory Pincus conduct the first tests using no- } \\
\text { rethynodrel and norethindrone to prevent ovulation }\end{array}$ \\
\hline 1955 & Searle's Frank Colton awarded a patent on norethynodrel \\
\hline 1956 & Large-scale trials begin to assess the drug's effectiveness as a contraceptive \\
\hline 1956 & Syntex's Carl Djerassi awarded a patent on norethindrone \\
\hline 1957 & $\begin{array}{l}\text { The FDA approves Syntex's Norlutin (norethindrone) and Searle's Enovid } \\
\text { (norethynodrel) for treatment of hormonal and other medical disorders }\end{array}$ \\
\hline 1960 & $\begin{array}{l}\text { The FDA approves the use of norethynodrel (Enovid) as an oral contracep- } \\
\text { tive for women }\end{array}$ \\
\hline 1961 & $\begin{array}{l}\text { The first reports of thromboembolism attributed to the pill surface in } \\
\text { Britain }\end{array}$ \\
\hline 1962 & Ortho Pharmaceutical Corp. enters the oral contraceptive market \\
\hline 1963 & $\begin{array}{l}\text { The FDA concludes that there is no connection between Enovid and } \\
\text { thromboembolism }\end{array}$ \\
\hline 1964 & Parke-Davis and Syntex enter the oral contraceptive market \\
\hline 1965 & $\begin{array}{l}\text { The U.S. Supreme Court in Griswold v. Connecticut overturns a Connecticut } \\
\text { law prohibiting the use of contraceptives on the grounds that it violates a } \\
\text { married couple's right to privacy }\end{array}$ \\
\hline 1968 & Papal encyclical is issued enjoining Catholics from using the pill \\
\hline 1969 & $\begin{array}{l}\text { Yale University opens one of the first college family planning clinics with ac- } \\
\text { cess to all students }\end{array}$ \\
\hline 1970 & $\begin{array}{l}\text { Senator Gaylord Nelson holds hearings investigating the health risks of oral } \\
\text { contraceptives }\end{array}$ \\
\hline 1970 & $\begin{array}{l}\text { The FDA requires informational pamphlet on health risks in every package } \\
\text { of birth control pills }\end{array}$ \\
\hline 1971 & $\begin{array}{l}\text { July 1, 1971, the } 26 \text { th Amendment is ratified; most states also lower the "age } \\
\text { of majority" }\end{array}$ \\
\hline 1972 & $\begin{array}{l}\text { The U.S. Supreme Court in Eisenstadt } v \text {. Baird overturns the Massachusetts } \\
\text { law prohibiting the sale of contraceptives to unmarried persons }\end{array}$ \\
\hline 1974 & $\begin{array}{l}\text { In Wisconsin Federal District Court, Baird v. Lynch overturns a law prohibit- } \\
\text { ing the sale of contraceptives to unmarried individuals (Civ. No. 71-C-254, } \\
\text { W.D. Wis.) }\end{array}$ \\
\hline
\end{tabular}


After they were enabled to obtain it, the pill diffused rapidly among single women. In 1976, 73 percent of all ever-contracepting single women 18 and 19 years old had used the drug (Zelnik and Kantner 1977, p. 63). ${ }^{8}$ Despite numerous "pill scares" concerning its medical complications, the pill has remained the contraceptive method of choice among fertile women independent of marital status. ${ }^{9}$

State laws did not prevent the determined single woman from obtaining contraceptive devices and information. Physicians routinely prescribed the pill to patients who said they were engaged because the pill is ineffective unless taken a month or two before sexual relations. Pretending to be engaged was one method of obtaining the pill (see, e.g., Scrimshaw 1981). The pill was also used to regulate menses, and some women obtained the pill by convincing a physician that they had irregular periods. ${ }^{10}$ Single women used the pill before state laws enabled them to, but their numbers were small, and the increase with the changes in state laws was substantial.

State laws in the 1960s were also in force to directly regulate the sale of contraceptives. These laws were the legacies of a federal antivice law passed in 1873, known as the Comstock Law. That law was relatively unimportant, but it served to fuel state "Comstockery" so that even by 1960, 30 states prohibited advertisements regarding birth control and 22 had some general prohibition on contraceptive sales. These laws reflected social norms and must have had a larger effect on minors, whose ability to obtain contraceptives was constrained in other ways.

The laws and social norms that prevented single women from obtaining the pill are barriers as well to our obtaining information on their use of the pill. A major survey of fertility and contraception taken in 1970-the National Fertility Survey (NFS)—excluded unmarried women. ${ }^{11}$ We know of only two surveys, prior to the 1980 s, that inquired

\footnotetext{
${ }^{8}$ Among single 18- and 19-year-old females in 1976, 30 percent had taken the pill, and among nonvirgins, 60 percent had (Inter-university Consortium for Political and Social Research 1982).

${ }^{9}$ In 1995, 48.3 percent of 25-34-year-old women who were nonsurgical contraceptors were on the pill and 51.3 percent of those 15-24 years old were. Among never-married women (15-44 years old), 49 percent of the nonsurgical contraceptors were on the pill (U.S. Department of Commerce 1999, p. 89).

${ }^{10}$ Pretending to be engaged and lying about a medical condition are demeaning acts. Because pill prescriptions had to be renewed, the demeaning act would have to be repeated regularly.

${ }^{11}$ According to the authors of the 1965 and 1970 NFS (Westoff and Ryder 1977), "The ideal, of course, would be to include all women of reproductive age, but the problems inherent in asking questions about fertility and contraception of never-married young girls have deterred us. The first such national study of teenaged girls has since been conducted by John Kantner and Melvin Zelnik .... The profession may be close to reconsidering this whole question" (p. 4). The 1970 NFS asked pill usage retrospectively, but only for women who were married a month before the date of the question.
} 
of the contraceptive use of young and unmarried women. ${ }^{12}$ These surveys have limited use, however, because they each cover 15-19-year-olds for only a year.

Just two data sets exist that enable the calculation of pill usage or family planning services for a large national sample of women regardless of current and prior marital status. Both give retrospective answers on use of the pill or family planning services. Each has the virtue that it enables the tracking of cohorts born from the late 1930s to the late 1960s and contains information on education and religion, among other relevant variables. Because our interest is in professional career choice, we concentrate on the diffusion of the pill among college graduate women. (Appendix table A1 describes data sets with contraceptive information.)

One of the surveys is the cancer risk factor supplement to the National Health Interview Study (NHIS) (Inter-university Consortium for Political and Social Research 1990). The almost 13,000 women interviewed in 1987 were asked, among other questions, their history of birth control pill usage. They were not asked their age at first marriage but did record the age at which they had their first birth.

Because the age at first marriage rose beginning with cohorts born around 1950, pill usage levels for unmarried women will be overstated in the NHIS, especially for the earliest cohorts considered. That is, we overstate the fraction of single women on the pill for all cohorts, but since a 21-year-old born in 1945 was more likely to be married than a 21-year-old born in 1950, the bias will be greater for the older group. To minimize the fraction of women who were already married, we include only those without a first birth before age 23. The fraction of these college graduate women first using the pill at various ages is graphed in figure $1 .^{13}$

According to these data, the fraction of women who began taking the pill after age 18 but before 20, that is, during college but before the usual age of majority, reached about 10 percent for cohorts born in 1945 (see fig. 1). Some of these women were married and, thus, able to obtain the pill. But even with this potential bias, a discernible increase in pill use can be seen for those born after 1946. First pill use in the

\footnotetext{
${ }^{12}$ Zelnik and Kantner (1972, 1989), Kantner and Zelnik (1977), and Inter-university Consortium for Political and Social Research (1982). We later use both surveys (1971 and 1976).

${ }^{13}$ The bias in fig. 1 could still be significant. Among college graduate women born from 1940 to the early 1950 s, about 25 percent had no births before age 23 but were already married by age 22 . This figure is only about 15 percent for those born from the late $1950 \mathrm{~s}$ to the early 1960s. (Estimates are derived from the merged 1990 and 1995 Current Population Survey Fertility and Marital History Supplements.) If pill usage were 30 percentage points higher for married than for single women, the overstatement for the older, relative to the younger, cohorts would be about three percentage points.
} 


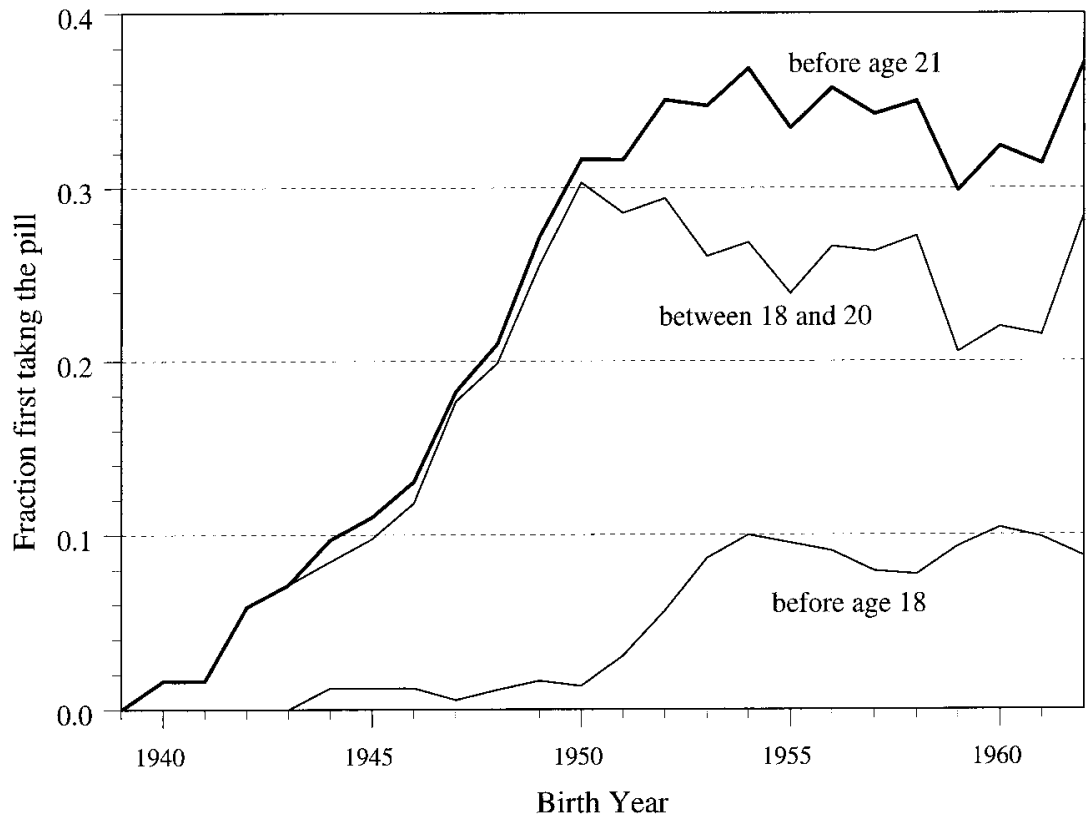

Fig. 1.-Fraction of college graduate women first taking the pill at various ages (among those with no births before age 23). Source: Inter-university Consortium for Political and Social Research (1990). Three-year centered moving averages are shown.

18-20-year interval reached 30 percent by the cohort born in 1950. For cohorts born after 1950, the increase in pill use among women younger than 21 years came about entirely from those obtaining the pill before age 18, a group with negligible use before. By the cohorts born in 1952, pill usage before age 21 was about 35 percent.

The absence of data in the NHIS on the age at first marriage is an obvious drawback. Therefore, we also use a survey that asked the age at first marriage and the year family planning services were first used, although it did not directly ask about first pill use. ${ }^{14}$ Birth control is just one family planning service, and the levels will, in consequence, be somewhat higher than for first pill use. ${ }^{15}$ The source is the National Survey of Family Growth, Cycle III, 1982 (Inter-university Consortium

${ }^{14}$ Akerlof, Yellen, and Katz (1996) use the 1982 National Survey of Family Growth, Cycle III (NSFG82) to construct a time series on the fraction of unmarried women on the pill at first sexual intercourse.

${ }^{15}$ More than 74 percent of first family planning visits, for those who were younger than 25 years in 1982, were for birth control (NSFG82), most of which were for the pill, which we can infer from the 1971 National Survey of Young Women (NSYW71). 


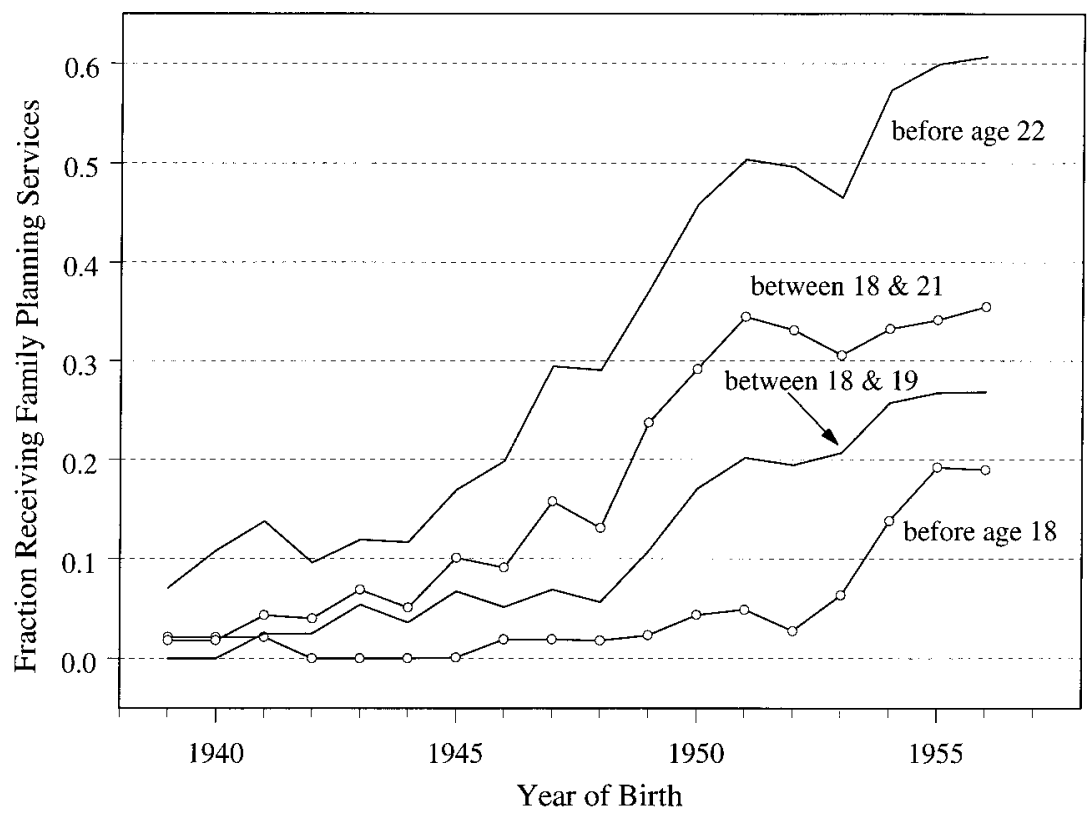

FIG. 2.-Fraction of college graduate women receiving first family planning services at various ages (among those not married by age 22). Source: Inter-university Consortium for Political and Social Research (1985). Three-year centered moving averages are shown.

for Political and Social Research 1985), which contains the responses of almost 8,000 women.

In figure 2 we graph the fraction of college graduate women receiving their first family planning services before and between various ages, among those not married before age 22. The fraction receiving services between ages 18 and 19 was 5 percent for the 1943-48 cohorts but subsequently rose to 27 percent by the 1956 cohort. Similarly, whereas only a small fraction of those younger than 18 received family planning services until the birth cohort of 1952, 20 percent did by the 1955 cohort. Likewise, the fraction receiving services between ages 18 and 20 rose gradually prior to the 1948 cohort but then rose steeply for the 1951 cohort.

The two data sets give relatively consistent results. Among women who would eventually graduate from college, the increase in contraceptive services for those of college age began with cohorts born around 1948, and among the pre-college aged, the increase began for cohorts born around 1952. Not surprisingly, the levels are somewhat higher for first family planning services than for first pill use, and the increase occurs 
somewhat earlier for the pill use series, which inadvertently includes more married women.

Because the surveys on which we rely for the timing of first pill use or family planning services are retrospective, there may be skepticism regarding their reliability. Do women reliably recall the year they first took the pill? There is overwhelming evidence that they do.

We compare the retrospective answers on first pill use in the NHIS with the nearly contemporaneous responses of women 15-19 years old in the National Survey of Young Women 1971 and the National Survey of Adolescent Female Sexual Behavior 1976 (NSAF76). The NSYW71 is a nationally based survey of 4,611 young women 15-19 years old in 1971 . Because we do not know whether those in the NSYW71 eventually graduated from college, we compare all 19-year-olds in the NSYW71 born in 1951 with all women in the NHIS born in 1952. Among those in the NHIS, 33 percent reported having taken the pill before age 20; among the group in the NSYW71, 34 percent claimed to have ever used birth control pills. ${ }^{16}$ The NSAF76 is also a nationally based survey of 15-19year-olds but about half the size of its predecessor version. We perform a similar comparison with it and the NHIS using women born in 1957. In the NHIS, among those born in 1957, 48.2 percent took the pill prior to age 20; in the NSAF76, among those born in $1957,51.2$ percent had ever taken the pill. ${ }^{17}$ This comparison offers strong evidence that women accurately recall when they first took the pill.

In sum, pill use by unmarried, college-educated women between 18 and 21 years old accelerated with cohorts born around 1948. For those younger than 18 years, pill use increased greatly with cohorts born around 1952. Although pill use among young, unmarried women greatly increased, peak usage among married women occurred about a half decade before rapid diffusion began for single women. One reason for the difference concerns state laws regarding the age of majority and mature minor statutes. The period of most rapid increase for unmarried women occurred when state laws changed.

\footnotetext{
${ }^{16}$ The figure using NSYW71 is computed for 19-year-olds born April-December 1951. Since the survey was taken in March 1971, none had completed their nineteenth year. If we instead use 19-year-olds born April-August 1951, the figure rises to 39 percent. Sample weights are used.

${ }^{17}$ The figure using NSAF76 is computed for 19-year-olds born March-December 1956. If we instead use 19-year-olds born March-July 1951, the figure rises to 56.1 percent. Sample weights are used.
} 


\section{B. $\quad$ State Variation in Laws Affecting Contraceptive Services}

The provision of contraceptive services to unmarried women younger than 21 years was highly circumscribed before the late 1960s. ${ }^{18}$ The majority of physicians understood that the law in most states required minors to obtain parental consent before nonemergency procedures, including contraceptive services, could be given. In 1969 the age of majority for females was 21 years old in all but nine states and was 18 years old in only six states (see table 2). State laws providing family planning services to young women were altered after 1969 in three ways. The age of majority was lowered in almost all states between 1969 and 1974. Statutes and judicial decisions began to classify minors as "mature" enough to make decisions, and laws were passed that allowed family planning services to be used by minors without parental consent.

In addition to the six states in 1969 having an age of majority for women of 18 years, three states (California, Georgia, and Mississippi) recognized the "mature minor" doctrine or provided family planning services to minors without parental consent. Thus in just nine states a woman of 18 years old could legally obtain the pill in $1969 .{ }^{19}$ Just two years later, in 1971, 16 states had an age of majority of 18 years and 17 (an additional 14) had laws that allowed women below the age of majority to obtain contraceptive services. Thus, in 1971, a woman of 18 years could, without legal hindrance, obtain the pill in 30 states. Females 16 years and younger could obtain it in 12 states (see table 2). In 1974, three years after the Twenty-sixth Amendment was ratified, just two states had an age of majority that exceeded 18 years and did not have legislation emancipating minors. ${ }^{20}$

The legal changes of the late 1960s and early 1970s regarding the age of majority and the mature minor doctrine were not generally motivated by demands for teenage contraception. Rather, the war in Vietnam was the main reason for the passage of the Twenty-sixth Amendment and the changes in the age of majority that preceded and followed its ratification. ${ }^{21}$ Reductions in the age of majority, in turn, often led to

\footnotetext{
${ }^{18}$ The same was true for unmarried women older than 21 in isolated areas, in college towns, or anywhere doctors felt constrained by social norms or personal morals.

${ }^{19}$ In five of the states (Arkansas, Idaho, Nevada, Oklahoma, and Utah), the age of majority for females was traditionally lower than it was for males, possibly because women married younger in these states.

${ }^{20}$ Today three states have an age of majority exceeding 18 years old (Alaska 19, Mississippi 21, and Pennsylvania 21), but no state, it appears, has any binding legislation preventing a minor from obtaining contraceptives. See the web site of the Alan Guttmacher Institute (http://www.agi-usa.org/pubs/ib21.html).

${ }^{21}$ According to Paul, Pilpel, and Wechsler (1974, p. 142), "The past five years have seen a marked expansion of the legal rights of teenagers. Most significant has been the reduction of the age of majority .... In the majority of cases, this development followed the adoption of the 26th Amendment to the U.S. Constitution which permits 18-year-olds to vote."
} 
TABLE 2

State Laws Regarding Contraceptive Services to Minors and the Age of MAJORITY, 1969-74

\begin{tabular}{|c|c|c|c|c|c|c|}
\hline \multirow[b]{2}{*}{ State } & \multicolumn{3}{|c|}{ AgE OF MAJORITY } & \multicolumn{3}{|c|}{$\begin{array}{c}\text { Earliest Legal Age to Obtain } \\
\text { Contraceptive Services with- } \\
\text { out Parental Consent }\end{array}$} \\
\hline & $\begin{array}{c}1969 \\
(1)\end{array}$ & $\begin{array}{c}1971 \\
(2)\end{array}$ & $\begin{array}{c}1974 \\
(3)\end{array}$ & $\begin{array}{c}1969 \\
(4)\end{array}$ & $\begin{array}{c}1971 \\
(5)\end{array}$ & $\begin{array}{c}1974 \\
(6)\end{array}$ \\
\hline Ala. & 21 & 21 & 21 & 21 & 17 & 17 \\
\hline Alaska & 19 & 19 & 19 & 19 & 19 & 14 or $19 *$ \\
\hline Ariz. & 21 & 18 & 18 & 21 & 18 & 18 \\
\hline Ark. & $18^{\dagger}$ & $18^{\dagger}$ & $18^{\dagger}$ & 18 & 14 & 14 \\
\hline Calif. & 21 & 21 & 18 & 15 & 15 & 15 \\
\hline Colo. & 21 & 21 & 21 & 21 & 14 & 14 \\
\hline Conn. & 21 & 21 & 18 & 21 & 18 & 18 \\
\hline Del. & 21 & 21 & 18 & 21 & 21 & 18 \\
\hline D.C. & 21 & 21 & 21 & 21 & 14 & 14 \\
\hline Fla. & 21 & 21 & 18 & 21 & 21 & 14 \\
\hline Ga. & 21 & 21 & 18 & 14 & 14 & 14 \\
\hline Hawaii & 20 & 20 & 20 & 20 & 20 & 20 \\
\hline Idaho & $18^{\dagger}$ & $18^{\dagger}$ & 18 & 18 & 18 & 14 \\
\hline Ill. & 21 & 18 & 18 & 21 & 14 & 14 \\
\hline Ind. & 21 & 21 & 18 & 21 & 21 & 18 \\
\hline Iowa & 21 & 21 & 18 & 21 & 21 & 14 or $18^{*}$ \\
\hline Kans. & 21 & 21 & 18 & 21 & 21 & 14 \\
\hline Ky. & 18 & 18 & 18 & 18 & 18 & 14 or $18^{*}$ \\
\hline La. & 21 & 21 & 18 & 21 & 21 & 14 \\
\hline Maine & 21 & 18 & 18 & 21 & 18 & 18 \\
\hline Md. & 21 & 21 & 18 & 21 & 18 & 14 \\
\hline Mass. & 21 & 21 & 18 & 21 & 21 & 18 \\
\hline Mich. & 21 & 21 & 18 & 21 & 14 & 14 \\
\hline Minn. & 21 & 21 & 18 & 21 & 18 & 18 \\
\hline Miss. & 21 & 21 & 21 & 14 & 14 & 14 \\
\hline Mo. & 21 & 21 & 21 & 21 & 21 & 21 \\
\hline Mont. & 21 & 19 & 18 & 21 & 19 & 18 \\
\hline Nebr. & 20 & 20 & 19 & 20 & 20 & 19 \\
\hline Nev. & $18^{\dagger}$ & $18^{\dagger}$ & 18 & 18 & 18 & 18 \\
\hline N.H. & 21 & 21 & 18 & 21 & 14 & 14 \\
\hline N.J. & 21 & 21 & 18 & 21 & 21 & 18 \\
\hline N.M. & 21 & 18 & 18 & 21 & 18 & 14 or $18^{*}$ \\
\hline N.Y. & 21 & 21 & 18 & 21 & 16 & 16 \\
\hline N.C. & 21 & 18 & 18 & 21 & 18 & 18 \\
\hline N.D. & 21 & 18 & 18 & 21 & 18 & 18 \\
\hline Ohio & 21 & 21 & 18 & 21 & 21 & 14 \\
\hline Okla. & $18^{\dagger}$ & $18^{\dagger}$ & 18 & 18 & 18 & 14 or $18^{*}$ \\
\hline Ore. & 21 & 21 & 18 & 21 & 15 & 15 \\
\hline $\mathrm{Pa}$. & 21 & 21 & 21 & 21 & 18 & 18 \\
\hline R.I. & 21 & 21 & 18 & 21 & 21 & 18 \\
\hline S.C. & 21 & 21 & 21 & 21 & 21 & 16 \\
\hline S.D. & 21 & 21 & 18 & 21 & 21 & 18 \\
\hline Tenn. & 21 & 18 & 18 & 21 & 14 & 14 \\
\hline Texas & 21 & 21 & 18 & 21 & 21 & 18 \\
\hline Utah & $18^{\dagger}$ & $18^{\dagger}$ & $18^{\dagger}$ & 18 & 18 & 18 \\
\hline Vt. & 21 & 18 & 18 & 21 & 18 & 18 \\
\hline Va. & 21 & 21 & 18 & 21 & 21 & 14 \\
\hline Wash. & 21 & 18 & 18 & 21 & 18 & 18 \\
\hline W.Va. & 21 & 21 & 18 & 21 & 21 & 14 or $18^{*}$ \\
\hline
\end{tabular}


TABLE 2

(Continued)

\begin{tabular}{|c|c|c|c|c|c|c|}
\hline \multirow[b]{2}{*}{ STATE } & \multicolumn{3}{|c|}{ Age of Majority } & \multicolumn{3}{|c|}{$\begin{array}{c}\text { Earliest Legal Age to Obtain } \\
\text { Contraceptive Services with- } \\
\text { out Parental Consent }\end{array}$} \\
\hline & $\begin{array}{c}1969 \\
(1)\end{array}$ & $\begin{array}{c}1971 \\
(2)\end{array}$ & $\begin{array}{c}1974 \\
(3)\end{array}$ & $\begin{array}{c}1969 \\
(4)\end{array}$ & $\begin{array}{c}1971 \\
(5)\end{array}$ & $\begin{array}{c}1974 \\
(6)\end{array}$ \\
\hline Wisc. & 21 & 18 & 18 & 21 & 18 & 18 \\
\hline Wyo. & 21 & 21 & 19 & 21 & 21 & 14 or $19 *$ \\
\hline Summary & States & States & States & States & States & States \\
\hline & $<20: 7$ & $<20: 18$ & $<20: 43$ & $\leq 16: 3$ & $\leq 16: 12$ & $\leq 16: 27^{\ddagger}$ \\
\hline
\end{tabular}

SouRCE. - 1969: Pilpel and Wechsler (1969). 1971: U.S. Department of Health, Education, and Welfare (1974). 1974: Paul et al. (1974). The coding of the laws is as of June 1974. 1974: U.S. Department of Health, Education, and Welfare (1978).

NoTE. - "Obtaining contraceptive services" means the ability to get the birth control pill. Some states had a different age for voluntary sterilization, and abortion laws occasionally differed as well. We use an age of 14 when the law was interpreted to mean that any minor could receive contraceptive devices without parental consent. Ala.: Law allows high school graduates and married women to obtain contraception, but not any female under the age of majority; therefore, an age of 17 is coded. Ark.: Age of majority is 18 , but recent law allows all women to get state family planning services except single women at college away from home, who should go to a private doctor. Conn.: Age of majority was reduced to 18 in 1972. An earlier law enabled any minor of 18 or older to obtain health services. Kans.: Legislation in 1966 allowed a physician to prescribe birth control to any woman at a public clinic, but the law was not universal. See, however, the discussion in Bailey (1997), which discusses the case of Lawrence, Kans. Ky: A "mature minor" decision majority is 21, but consent rights are given to those 18 years and older for contraceptive services. Mich.: Age of majority is lowered to 18 in 1972. Minn.: Law states that minors living apart from their parents can give consent to health services; thus the age in 1971 is given as 18 since it does not provide blanket coverage for 14-17-year-olds. N.J.: Age of majority is lowered to 18 in 1973. N.Y.: Pharmacists may sell contraceptives to minors 16 and older. The law was ambiguous with regard to physicians and parental consent. Ohio: Ohio has a mature minor doctrine established in 1956, but its relevance to birth control is unclear in 1971. Pa.: Minors 18 years and older (or high school graduates) may consent to any medical care. Va.: Age of majority is lowered to 18 , and any individual under age 18 may consent to birth control individuals was put in question after the Eisenstadt v. Baird (1972) decision regarding a similar Massachusetts law.

$*$ The state has a comprehensive family planning program that does not exclude the provision of contraceptive services to minors, but there is either no mature minor doctrine in the state or no clear decision by the state attorney general concerning the legality of such a provision

${ }^{+}$Age of majority is 18 for females and 21 for males.

Seven states are ambiguous cases.

extensions of the mature minor doctrine. Of the 21 states that changed their regulations between 1969 and 1971, 10 reduced the age of majority, 10 instituted a mature minor doctrine, and one instituted a family planning act. ${ }^{22}$

Some ambiguity surrounds the meaning of these legal changes. In no state was it per se illegal in 1972, for example, to prescribe or sell contraceptives to a minor. ${ }^{23}$ Rather, the legality both before and after

${ }^{22}$ The 1967 amendment to Title IV of the Social Security Act (Aid to Families with Dependent Children) requires state and local welfare agencies to provide contraceptive services to eligible individuals without regard to marital status and age. But this law would not have affected the ineligible population, and it is unclear how it affected teenagers in states without a mature minor doctrine.

${ }^{23}$ Until 1966 it was illegal in Massachusetts to sell contraceptives. The law was modified after Griswold v. Connecticut (1965). From 1966 to 1972, it was illegal to sell contraceptives to unmarried persons, and sale to married persons required a prescription. That law was struck down by the U.S. Supreme Court in Eisenstadt v. Baird (March 1972). A similar Wisconsin law was overturned in Baird v. Lynch (1974, Civ. No. 71-C-254, W.D. Wis.). See U.S. Department of Health, Education, and Welfare $(1974,1978)$. There is no evidence that these laws were rigorously enforced. 
1972 hinged on whether the minor was "emancipated" by marriage, parental consent, or statute. But even then, medical services depended on whether the physician believed that it was in the best interests of the patient and was consistent with local practice.

Universities and colleges viewed the legal ambiguity in the late 1960s as good reason not to provide family planning services and certainly not to advertise the availability of services offered on an individual basis. Only after the age of majority was lowered and the mature minor doctrine was established did university health services offer family planning to undergraduates and advertise its availability. ${ }^{24}$ The availability of family planning services to women when they are in college is a critical input to career change because it occurs when career, marriage, and family decisions are being made. The point is central to our analysis since access to the pill was not a major issue for most women after they were in professional and graduate school. ${ }^{25}$

According to the American College Health Association (ACHA), just 12 institutions in 1966 (3.6 percent of those reporting) would prescribe the pill to unmarried students (Barbato et al.1968; Barbato 1971).$^{26}$ In 1973, according to an extensive survey of colleges, 19 percent would provide family planning services to students regardless of age and marital status. ${ }^{27}$ Because larger schools had a higher fraction providing services, about 42 percent of undergraduates would have been able to obtain such services (Hollis and Lashman 1974). ${ }^{28}$ Thus, although in 1966 few student health services would prescribe the pill to unmarried women, by 1973 more than two-fifths of all undergraduates, regardless

${ }^{24}$ Yale University was in the forefront and opened a family planning clinic in 1969, prompted by a change in student needs with coeducation (Sarrel and Sarrel 1971). Other institutions rapidly followed.

${ }^{25}$ Many people have told us that after the pill's diffusion, college mentors and those on professional and graduate school acceptance committees took female students more seriously.

${ }^{26}$ In the 1970 ACHA survey, about 35 percent of member institutions claimed that they would prescribe the pill to unmarried minors (although a low reporting rate biases this statistic upward). The nonmember institutions had far lower fractions prescribing to all students (12 percent) and even lower reporting rates than member institutions (Hollis and Lashman 1974).

${ }^{27}$ No extant records of the 1973 survey exist, so institutional identities are not known. The Wall Street Journal ("The Pill on Campus," 1970) reported that various universities-among them the University of California at Berkeley, Davis, Los Angeles, Santa Barbara, and San Diego; the Universities of Michigan, Chicago, Illinois, and Washington; and Cornell, Yale, and Northwestern Universities—had recently established, or were about to open, unrestricted family planning clinics for all students.

${ }^{28}$ The 1973 survey was done by the National Center for Health Statistics and the ACHA, and it covered 2,984 institutions (92 percent response rate). The 42 percent figure is our estimate based on a table in Hollis and Lashman (1974). Only the 1973 ACHA survey is sufficiently complete to provide an estimate of the fraction of undergraduates who could obtain family planning services on campus. 
of marital status and age, could receive family planning services on campus, and others could obtain them locally without parental consent.

\section{The Impact of State Laws on Pill Use}

Did states with more lenient laws regarding access to contraceptive services by minors have higher pill use by young unmarried women? The NSYW71 is the only data set, of which we are aware, that pertains to the most relevant time period (the very early 1970s) and has information on pill use and state of residence for female teenagers. ${ }^{29}$ We have coded the respondent's state of residence according to whether the state was governed by the mature minor doctrine or had a comprehensive family planning statute, both of which would have enabled young women (16 years and older) to obtain the pill. Twelve states fit that description in 1971, with seven states having a minimum age of 14 or 15 years (see col. 5 of table 2).

The estimation in table 3 is given for all never-married women (cols. 1,3 , and 5) and for those who ever had sexual relations (cols. 2, 4, and 6 ). The effect on pill use of being in one of the nonrestrictive states, relative to the mean of the dependent variable, is quite similar for the two estimations. Included in the regressions are covariates for age, education, current school attendance, religion, race, and census division.

States with more lenient regulations regarding minors had greater pill use by young unmarried women. For 15-19-year-olds, pill use was 33-35 percent greater in less restrictive states (cols. 1 and 2); for the 17-19-year-olds, it was 36-40 percent greater (cols. 3 and 4). The increase was largest for all college women (col. 5), perhaps because most university health services carefully followed the law and offered family planning services when the law changed. ${ }^{30}$

In states with more permissive laws, young women appear to have had greater access to the pill. But despite our emphasis on changes in laws, we also recognize the porosity of the laws and the role of social norms. Even before 1970, change was "in the air" regarding the rights of young people. The 1967 social security amendment allowing poor women to obtain family planning services without regard to marital status or age was a signal to physicians. States often had ambiguous laws that enabled county health departments to extend contraceptive services to all women

\footnotetext{
${ }^{29}$ The NSAF76 does not have state of residence, and, even if it did, it would be too late.

${ }^{30}$ The magnitudes of the estimated effects of a nonrestrictive state law in cols. 1-4 of table 3 are not much affected by adding state per capita income to the regressions. The coefficients on the state law variable for the subsample of college women in cols. 5 and 6 are reduced in magnitude, and the standard errors increased substantially, by the inclusion of state per capita income. For nonsouthern states, the income and the state law variables are highly correlated.
} 
TABLE 3

State Laws and Pill Use among Never-Married Female Youths in the National SuRvey OF Young WOMEN, 1971

Dependent Variable: 1 = Ever Taken the Birth Control Pill

\begin{tabular}{|c|c|c|c|c|c|c|}
\hline & \multicolumn{2}{|c|}{ 15-19 Years Old } & \multicolumn{2}{|c|}{ 17-19 Years Old } & \multicolumn{2}{|c|}{$\begin{array}{c}\text { 17-19 Years Old } \\
\text { AND ATTENDS } \\
\text { COLlege }\end{array}$} \\
\hline & $\begin{array}{l}\text { All } \\
(1)\end{array}$ & $\begin{array}{l}\text { Sexually } \\
\text { Active* } \\
\text { (2) }\end{array}$ & $\begin{array}{l}\text { All } \\
(3)\end{array}$ & $\begin{array}{l}\text { Sexually } \\
\text { Active } \\
\text { (4) }\end{array}$ & $\begin{array}{l}\text { All } \\
(5)\end{array}$ & $\begin{array}{c}\text { Sexually } \\
\text { Active } \\
(6)\end{array}$ \\
\hline $\begin{array}{l}\text { Mean of dependent } \\
\text { variable }\end{array}$ & .0652 & .245 & .106 & .304 & .145 & .406 \\
\hline $\begin{array}{l}\text { State law }(1=\text { nonre- } \\
\text { strictive for } \\
\text { minors })\end{array}$ & $\begin{array}{l}.0232 \\
(.00870)\end{array}$ & $\begin{array}{l}.0807 \\
(.0280)\end{array}$ & $\begin{array}{l}.0422 \\
(.0153)\end{array}$ & $\begin{array}{l}.109 \\
(.0372)\end{array}$ & $\begin{array}{l}.0701 \\
(.0367)\end{array}$ & $\begin{array}{l}.128 \\
(.0889)\end{array}$ \\
\hline \multicolumn{7}{|l|}{ Age variables: } \\
\hline 15 & $\begin{array}{c}-.140 \\
(.210)\end{array}$ & $\begin{array}{l}-.259 \\
(.0641)\end{array}$ & & & & \\
\hline 16 & $\begin{array}{l}-.119 \\
(.0186)\end{array}$ & $\begin{array}{l}-.175 \\
(.0521)\end{array}$ & & & & \\
\hline 17 & $\begin{array}{r}-.0946 \\
(.0163)\end{array}$ & $\begin{array}{l}-.106 \\
(.0443)\end{array}$ & $\begin{array}{r}-.0730 \\
(.0202)\end{array}$ & $\begin{array}{r}-.0837 \\
(.0470)\end{array}$ & $\begin{array}{l}-.114 \\
(.0491)\end{array}$ & $\begin{array}{c}-.103 \\
(.146)\end{array}$ \\
\hline 18 & $\begin{array}{r}-.0618 \\
(.0618)\end{array}$ & $\begin{array}{c}-.0941 \\
(.0334)\end{array}$ & $\begin{array}{r}-.0544 \\
(.0170)\end{array}$ & $\begin{array}{r}-.0836 \\
(.0373)\end{array}$ & $\begin{array}{r}-.0602 \\
(.0293)\end{array}$ & $\begin{array}{r}-.0632 \\
(.0664)\end{array}$ \\
\hline \multicolumn{7}{|l|}{ Education variables: } \\
\hline College & & & $\begin{array}{l}.0680 \\
(.0177)\end{array}$ & $\begin{array}{l}.177 \\
(.0430)\end{array}$ & & \\
\hline $\begin{array}{l}\text { Currently attends } \\
\text { school }\end{array}$ & $\begin{array}{r}-.0820 \\
(.0158)\end{array}$ & $\begin{array}{r}-.0695 \\
(.0364)\end{array}$ & $\begin{array}{r}-.0714 \\
(.0189)\end{array}$ & $\begin{array}{r}-.0845 \\
(.0405)\end{array}$ & $\begin{array}{l}-.211 \\
(.0846)\end{array}$ & $\begin{array}{c}-.323 \\
(.161)\end{array}$ \\
\hline Catholic & $\begin{array}{l}-.0126 \\
(.00845)\end{array}$ & $\begin{array}{c}-.0272 \\
(.0287)\end{array}$ & $\begin{array}{r}-.0210 \\
(.0149)\end{array}$ & $\begin{array}{r}-.0426 \\
(.0374)\end{array}$ & $\begin{array}{l}-.0256 \\
(.0334)\end{array}$ & $\begin{array}{r}-.0804 \\
(.0819)\end{array}$ \\
\hline African-American & $\begin{array}{l}.0775 \\
(.0112)\end{array}$ & $\begin{array}{l}.0656 \\
(.0284)\end{array}$ & $\begin{array}{l}.101 \\
(.0193)\end{array}$ & $\begin{array}{l}.0405 \\
(.0379)\end{array}$ & $\begin{array}{l}-.0276 \\
(.0505)\end{array}$ & $\begin{array}{c}-.186 \\
(.0958)\end{array}$ \\
\hline Observations & 4,211 & 1,314 & 2,226 & 890 & 647 & 245 \\
\hline$R^{2}$ & .0854 & .113 & .0645 & .0856 & .0558 & . 103 \\
\hline
\end{tabular}

SOURCE, - National Survey of Young Women, 1971.

NoTE.-Standard errors are in parentheses. Ordinary least squares estimates are given and are almost identical to the implied slopes estimated by a logit and evaluated at the sample means. All regressions use the NSYW71 sampling weights. State law is coded one if, in 1971, the state allowed minors (16 years and older) to receive birth control services and devices without parental consent. There were 12 states in that group; see col. 5 of table 2. Dummy variables are included in cols. 1 and 2 for grades 8 and above, and dummy variables are included for census divisions in all columns. About 3 percent of the sample in cols. 5 and 6 were not attending college at the time of the survey but reported that they attended college.

* "Sexually active" means that the individual had ever had sexual intercourse.

(see Bailey [1997] for a case study of Kansas). Thus pill use by young, single women began to rise about a year before the sea change in the laws regarding the age of majority.

\section{Frameworks to Understand the Effect of the Pill on Marriage and Career}

We have established that the birth control pill diffused rapidly among young, unmarried women beginning in the late 1960s and that the 
timing was related to changes in state laws and a growing notion that young people could make their own decisions. But how could the diffusion of the pill have affected professional career investments by young women?

The diffusion of the pill among young, single women may have altered career decisions through two routes: direct and indirect. By the direct effect of the pill, we mean the reduction in the cost of marriage delay. The pill makes marriage delay and thus career investment cheaper, and women with greater "career ability" become more attractive marriage partners. By the indirect effect of the pill, we mean the lowering of the cost of a career through the marriage market. This effect, in contrast, operates through a thickening of the marriage market for those who delay marriage and leads to better matches for career women and some others. To simplify the discussion, we formally model the direct effect and give the intuition behind the indirect effect. ${ }^{31}$

Consider a cohort of $n$ women and $n$ men, each initially unmarried, in a two-period context with no discounting. Members of each sex agree on the ranking of the other in terms of marriage partners. Each man brings $Y_{i}$ (e.g., income), known to all, to marriage. Each woman brings $N_{j}$ (e.g., nurturing), known to all, to marriage and can also contribute $\alpha_{j}$ through a career; $\alpha_{j}$ is treated as a household public good. We make the simplifying assumption that career investment is not possible if a woman marries in period 1 . Marriage delay reduces utility by $\lambda$ for each partner. The reduction is assumed to be the same for all men and women and $\lambda=\lambda_{0}$ prior to the introduction of the pill. We interpret $\lambda$ as the utility lost from abstinence as well as from forgone home production and term $\lambda$ the "impatience factor" to encompass both. The attributes $Y, N$, and $\alpha$ are distributed among the $n$ men and women such that $Y \sim[\underline{Y}, \bar{Y}], N \sim[\underline{N}, \bar{N}]$, and $\alpha \sim[\underline{\alpha}, \bar{\alpha}]$, where $\underline{Y}, \underline{N}, \underline{\alpha}>0$. The distributions of $Y, N$, and $\alpha$ are known by all participants, and each individual's attributes are perfectly observable.

Consider a match between male $i$ and female $j$. If they marry in period 1, then the male gets $N_{j}$ and the female gets $Y_{i}$. If they delay marriage to period 2 and the woman invests in a career, then the male gets $N_{j}+\alpha_{j}-\lambda_{0}$ and the female gets $Y_{i}+\alpha_{j}-\lambda_{0}$. If $\alpha_{j}>\lambda_{0}$, then both benefit from delay and the woman will invest in a career in period 1. If, instead, $\alpha_{j}<\lambda_{0}$, they marry in period 1 and the woman has no career. Since there are no disagreements, we can unambiguously match men and women on the basis of their value in marriage to the other sex.

Men's attractiveness to women is completely summarized by $Y_{i}$.

${ }^{31}$ See Bergstrom and Bagnoli (1993) for a related model of decisions to delay marriage by men and the determinants of marriage age differences by sex. We consider models of single age cohorts of males and females and thereby abstract from the possible impact of the pill on sex differences in the age at marriage. 


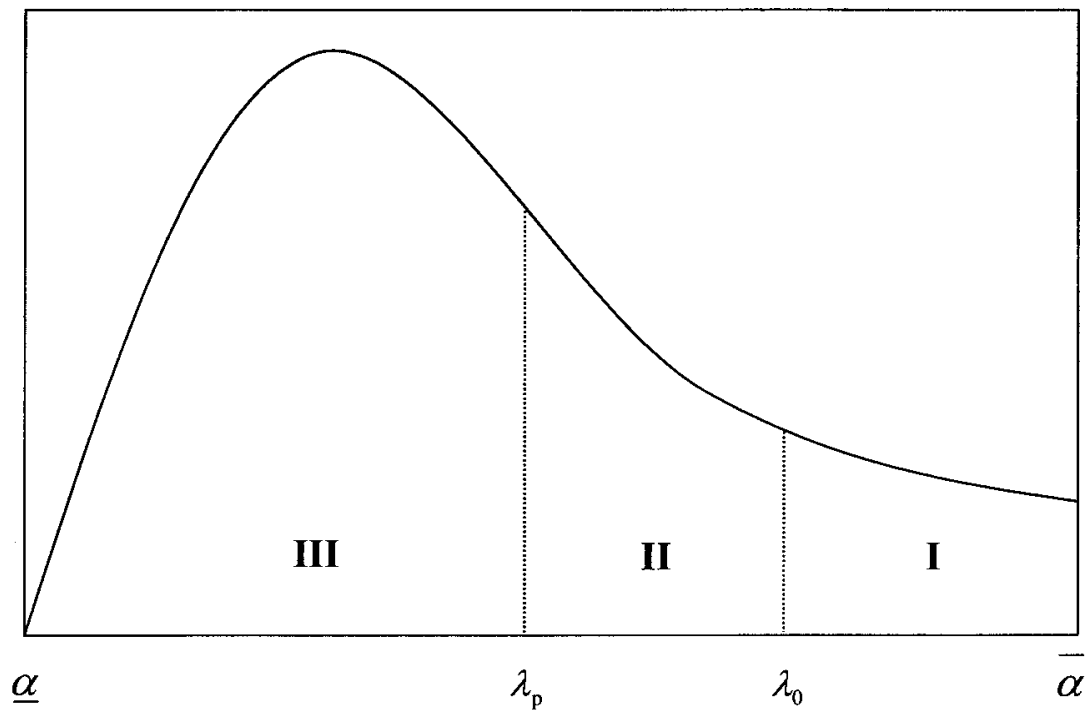

FIG. 3.-Distribution of career ability, $\alpha$, and shifts in the "impatience" factor, $\lambda$, with the pill.

Women's attractiveness to men, on the other hand, depends on $F_{j}=$ $\max \left[N_{j},\left(N_{j}+\alpha_{j}-\lambda_{0}\right)\right]$. The marriage market operates at the start of period 1 by matching men and women by their ranking in terms of $Y_{i}$ and $F_{j}$. The highest-ranked male gets matched to the highest-ranked female, and so on down the distribution. As depicted in figure 3 , all women with $\alpha_{j} \geq \lambda_{0}$ invest in careers and delay marriage until period 2; all others marry in period 1 .

The pill reduces $\lambda$, say from $\lambda_{0}$ to $\lambda_{p}$, and shifts down the cutoff point in the $\alpha$ distribution for careers. The fraction of women with careers and the fraction of women delaying marriage increase by the same amount. Even with no change in matching there will be an increase in marriage delay and in career investment. But matching will, in general, change because the pill enhances the relative attractiveness of women with high career values (high $\alpha_{j}$ ). Thus the $F_{j}$ distribution will shift with the decline in $\lambda$.

Three groups of women can be distinguished. Group I women, those for whom $\alpha_{j}>\lambda_{0}$, delay marriage and have a career with or without the pill. The pill increases the value in marriage of each woman in this group by $\Delta F_{j}=\lambda_{0}-\lambda_{p}$. Group II women, those for whom $\lambda_{0}>\alpha_{j}>$ $\lambda_{p}$, marry in period 1 in the absence of the pill but delay marriage and have a career with the pill. The pill increases the marriage value of each 
by $\Delta F_{j}=\alpha_{j}-\lambda_{p}$. Group III includes those for whom $\alpha_{j}<\lambda_{p}$. These women do not have a career with or without the pill, and they lose from the pill since some become matched to worse partners. ${ }^{32}$ Men are unambiguous winners from the introduction of the pill. Women are, on average, winners, but those in group III lose.

In our modeling of the direct effect, the pill lowers the price of delay and thus encourages later marriage and greater career investment. But the increase in the number of women who delay marriage has no effect on the decisions of other women. The pill, however, probably also had a "social multiplier" effect in the following manner. Assume that, in the absence of a highly effective form of contraception, couples marry "too early," that is, before their true type is revealed even to them. The pill could then produce a new equilibrium in which marriages are later, careers are more numerous, and matches are "better." When marriage is delayed, mismatch in the marriage market, a potential career cost, is reduced. As people marry later, even more will be enticed to do so to obtain a better match. Women and men who delay marriage because of the pill can thereby give rise to a social multiplier effect. ${ }^{33}$ Careers will be fostered indirectly through a thicker marriage market and will be fostered even for women who do not take the pill. The improvement in the quality of marriage matches from delay in marriage and better information at the time of marriage could also potentially lead to a reduction in the divorce rate.

Our framework illustrates how the introduction of the pill may have altered women's career and marriage choices. Because up-front, timeintensive career investments are difficult for women with child care responsibilities, the pill encouraged women's careers by virtually eliminating the risk of pregnancy. But the pill did far more than control the number and timing of births. It also altered the marriage market.

The pill enabled young men and women to put off marriage while not having to put off sex. Sex no longer had to be packaged with commitment devices, many of which encouraged early marriage. Before the pill was widely available, young people devised means to secure commitments that enabled sexual relations. They "went steady," fraternity men "pinned" coeds, and couples got "engaged." If a pregnancy resulted, the couple generally got married (Akerlof et al. 1996).

The decrease in the cost of marriage delay altered the rankings of women as potential marriage partners and favored those with good career prospects. The greater number of individuals delaying marriage,

\footnotetext{
${ }^{32}$ Akerlof et al. (1996) develop related models of how the legalization of abortion (and availability of contraceptives) changes norms concerning shotgun marriages and out-ofwedlock births. Some women benefit. But those unwilling, or unable, to get an abortion or use the pill are adversely affected.

${ }^{33}$ For a formal modeling of the social multiplier effect, see Goldin and Katz (2000).
} 
in turn, created a thicker marriage market for others. The indirect effect of a thicker marriage market for career women led even more women to opt for careers and delay marriage. An increase in the age at first marriage may also have led to higher-quality matches, if preferences are not fully formed at younger ages.

The key empirical predictions of the framework are that the introduction of the pill should have been associated with an increase in professional careers for women, the age at first marriage, and the age at first birth. Positive assortative mating on earnings capacity and compatibility among marriage partners should also have increased. The new equilibrium, however, is not completely "win-win." Women with poorer labor market prospects may suffer a decrease in their rankings as marriage partners and be the losers in the era of the pill. The framework does not produce unambiguous predictions with respect to divorce. Better matches should result from the pill, but increased career prospects for women outside marriage, decreased division of labor in the home, and potentially fewer children could all increase divorce.

\section{Evidence for the Power of the Pill}

We present both descriptive time-series and formal econometric evidence to examine the notion that the pill had meaningful social and economic consequences. The descriptive time-series evidence is a set of coincident turning points in pill use among young, single women, career investment, and the age at first marriage, among other indicators. The formal econometric analyses using cross-cohort variation in pill usage at college ages and cross-state variation in changes in state laws affecting pill access for young, unmarried women are suggestive of a causal relationship between pill use and changes in college women's career investment and marriage.

\section{A. Time Series: Career Investment, Marriage, Sex, and Fertility Expectations}

\section{Career Investment}

The most relevant careers to study in the context of our framework are those that require extensive, up-front education, such as the professions of law, medicine, dentistry, and business administration. We express the time-series data on the professional school enrollments of women in two ways: as a share of women receiving the bachelor of arts (B.A.) 
degree in the same year and as a share of total first-year enrollments in professional schools (fig. 4). ${ }^{34}$

As a fraction of B.A.'s, female entrants to law and medical schools began a steep climb around 1970. The increase, moreover, peaked in about a decade. The female share of first-year students in four major professional degree programs (medicine, law, dentistry, and business) also shows a sharp break around 1970. Throughout the 1960s the ratio of women to all students was around 0.1 in medicine, 0.04 in law, 0.01 in dentistry, and 0.03 in business administration. By 1980 it was 0.3 in medicine, 0.36 in law, 0.19 in dentistry, and 0.28 in business. ${ }^{35}$

Career decisions of young women changed abruptly around 1970. The shift, moreover, did not arise from an increase in the fraction of female applicants admitted, at least not in the case of medical students. The change in the sex composition resulted almost entirely from an increase in applications by women to medical school. ${ }^{36}$

The large increases in women's enrollment in lengthy professional training programs, starting around 1970, resulted in a sharp rise in women's presence in law, medicine, and other professions across the past three decades. The percentage of all lawyers and judges who are women more than doubled in the 1970s (from 5.1 percent in 1970 to 13.6 percent in 1980) and was 29.7 percent in 2000. The share of female physicians increased from 9.1 percent in 1970 to 14.1 percent in 1980 and was 27.9 percent in 2000. Similar patterns are apparent for occupations such as dentists, architects, veterinarians, economists, and most of the engineering fields. ${ }^{37}$

${ }^{34}$ The vast majority of first-year professional students are recent B.A.'s. We have also examined the change in undergraduate majors from the mid 1960s to the late 1970s. The fraction of female B.A.'s majoring in traditionally female concentrations (e.g., education and English) decreased from the mid 1960s, but with far greater speed after 1971. The fraction majoring in the physical and biological sciences, math, and engineering decreased a bit until 1971 but subsequently rose steeply.

${ }^{35}$ The ratio of female to male professional school students continues to rise even when the percentage of female B.A.'s who enter professional school does not. The reason is beyond the scope of this paper and concerns the decrease in the share of male B.A.'s, and of all B.A.'s, entering professional schools.

${ }^{36}$ See Cole (1986) and Goldin and Katz (2000) for evidence that virtually all of the increase in female medical students, beginning around 1970, resulted from an increase in applications from women.

${ }^{37}$ Overall, the female share of employment in professional occupations (excluding teachers of kindergarten through grade 12 and health assessment occupations such as nurse) increased from 19.9 percent in 1970, to 27.4 percent in 1980, and to 37.5 percent in 2000 . The female share of these occupations barely changed from 1950 to 1970 . (The 1950-80 data are tabulated from the Integrated Public Use Microdata Series [Ruggles and Sobek 1997]; those for 2000 are taken from U.S. Department of Labor [2001, table 11].) Furthermore, cohort-based analyses show large increases in the share of women younger than 40 years gaining employment in high-wage professional and managerial occupations starting with cohorts born in the late 1940s to early 1950s (Black and Juhn 2000). 

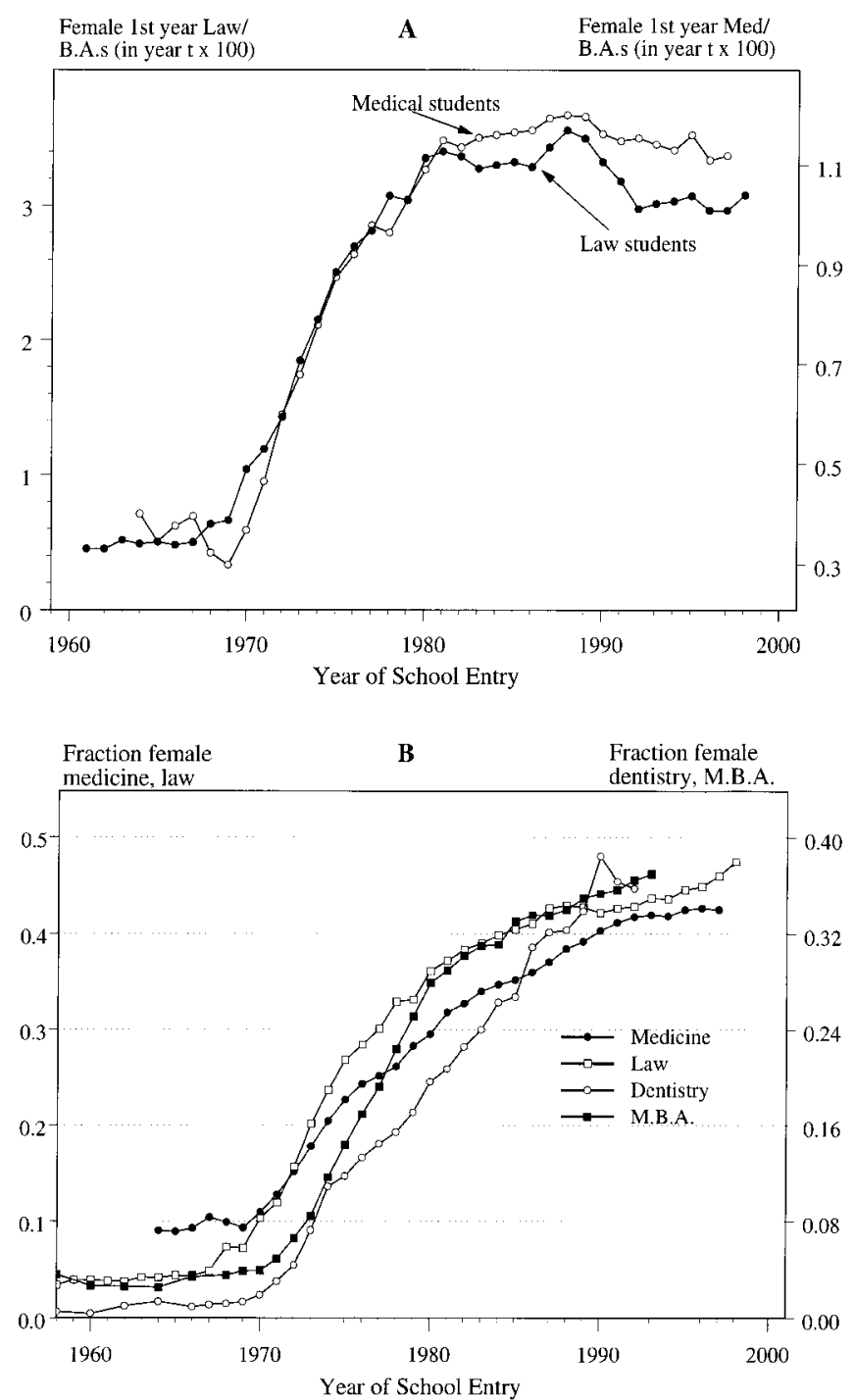

Fig. 4.-First-year female professional students as a percentage of female B.A.'s (panel $A$ ) and as a fraction of first-year students (panel $B$ ). Source: B.A. degrees: U.S. Department of Education (1998), table 244. First-year medical students: Journal of the American Medical Association (various years 1978-98). First-year law students: American Bar Association web site (http://www.abanet.org/legaled/femstats.html). First professional degrees in dentistry: U.S. Department of Education (1998), table 259. Earned degrees in business: U.S. Department of Education (1997), table 281. Note: Data for first-year dental and business students are derived from first professional degrees lagged four years for dental students and three years for business students. The data, for years of overlap, are similar to those for first-year students from Students Enrolled for Advanced Degrees (U.S. Department of Health, Education, and Welfare, various years). The procedure, moreover, produces values similar to those for medicine and law for which the first-year student time series exists. 


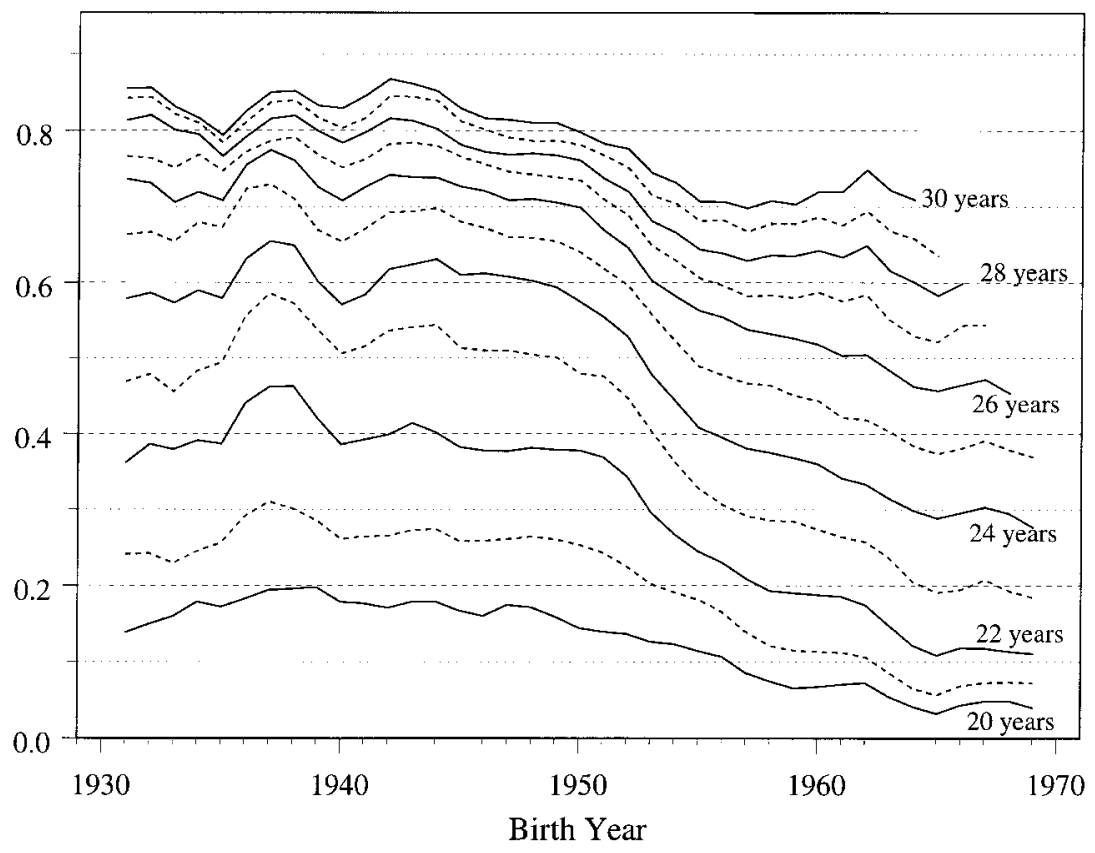

Fig. 5.-Fraction of college graduate women married before various ages. Source: Current Population Survey, Fertility and Marital History Supplement, 1990 and 1995. Threeyear centered moving averages are shown.

\section{Age at First Marriage, Sex, and Fertility Expectations}

According to our framework, the pill loosened constraints and lowered the impatience factor, $\lambda$. Couples could engage in sex without commitments; marriage could be delayed. But did it happen? Marriages were delayed considerably beginning with the birth cohorts of the late 1940 s, precisely those affected by the pill, and the age at first sexual relations among the never-married also decreased, again in line with the cohorts affected by the availability of the pill.

In figure 5, we graph the fraction of college graduate women married before ages ranging from 20 to 30 years. About 50 percent of those born from 1941 to 1949 married before age 23 (the median age of a college graduate is 22 years). After 1949, however, the fraction married before age 23 or 24 plummeted. By the cohort born in 1957, the fraction married before age 23 was 30 percent, or fully 20 percentage points lower than in 1950. Thus the fraction of women who married about a year after college graduation declined precipitously after 1972 and fol- 
lowing changes in most states regarding laws governing access to contraceptives for youth.

Our argument concerning the impact of the age at first marriage on career requires that women who invest in careers generally delay marriage. We have examined registration cards for Harvard University Law School students in the entering classes of 1962-75. Because the cards were used for diplomas, recorded names were routinely updated ${ }^{38}$ We find that for classes graduating from 1970 to 1972 (born from 1945 to 1947), the fraction married at the time of law school graduation was about one-third the national average by age and birth year, but was about the national average for those graduating between 1964 and 1966 (born from 1941 to 1943).$^{39}$ Thus the marriage rate for the cohorts that greatly increased their numbers in law school was significantly below the average for college graduate woman.

The fraction engaging in sex before various ages is given in figure 6 , for which we analyze all women, not just college women, because of small sample sizes. ${ }^{40}$ The evidence is strikingly consistent with the timing of pill availability to young, unmarried women. Sexual activity among the group under 20 years increased with cohorts born after 1947, and even for the younger group (under 18 years) the increase began with cohorts born around 1952.

Fertility expectations of college women plunged from the mid 1960s to the early 1970s. In 1963, 80 percent of non-Catholic female college students desired three or more children and 44 percent wanted at least four. Ten years later, in 1973, just 29 percent wanted three or more and almost 10 percent wanted none..$^{41}$ Neither cohort had as many children as "desired," but their desires reflected trade-offs they were willing to make between family and career.

\footnotetext{
${ }^{38}$ We cannot use the records after it became more common for women to keep their maiden names. Until 1972, the cards requested information on marital status at time of registration. We also verified whether a woman's last name matched her father's. Since some women in the 1970-72 classes married but did not change their names, we may understate the fraction marrying while in law school.

${ }^{39}$ Entering marriage rates are much lower than the national average for college graduate women in all years. The marriage rates in law school are extremely high for the classes in the mid 1960s, when there were only about 20 women in each class and, thus, about 18 male students for every female.

${ }^{40}$ The source of the data is the NSFG82. Similar patterns are found when the sample is restricted to women with some college. To assess the accuracy of the information, we also use a more contemporaneous measure from the NSYW71 and NSAF76 (given as solid markers). The two measures are, with one exception, remarkably consistent.

${ }^{41}$ For the 1963 data, see Westoff and Potvin (1967, table 7). We use only non-Catholic women in nonsectarian schools since Westoff and Potvin oversampled religious institutions but do not give the population weights. The 1973 data are tabulated from the National Longitudinal Survey of Women 14-24 (Ohio State University 1968-91) and include all who ever graduated from a four-year institution of higher education and who were of approximate college age in 1973.
} 


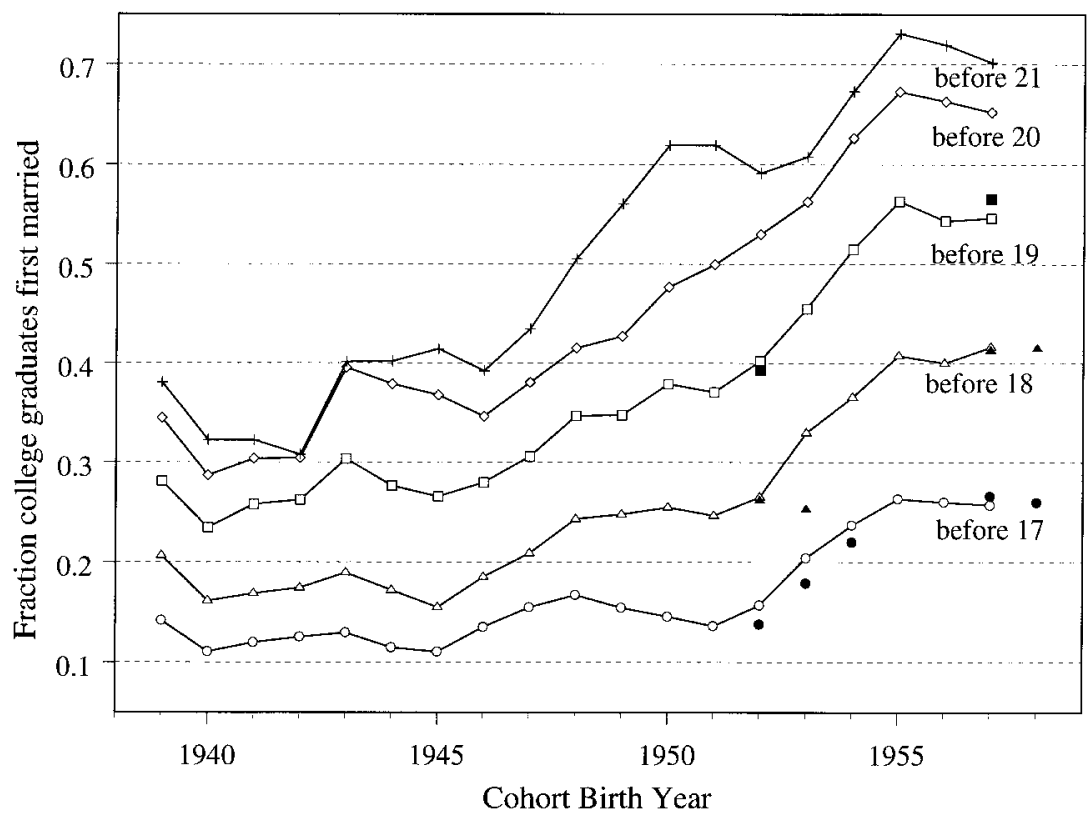

Fig. 6.-Fraction of never-married women having sex before various ages. Source: All but the solid markers: Inter-university Consortium for Political and Social Research (1985). Solid markers for birth cohorts of 1952, 1953, and 1954: Zelnik and Kantner (1989). Solid markers for birth cohorts of 1957 and 1958: Inter-university Consortium for Political and Social Research (1982). Three-year centered moving averages are shown. Solid markers, of the same shape as the open markers, give the values for contemporaneous data.

\section{B. Formal Econometric Analyses: Marital Status and Professional Career Outcomes}

1. Age at First Marriage and State Law Changes in Pill Access

Although we have made a case for the coincident turning points in the various series, we have not yet directly established whether pill availability altered the age at first marriage. To assess this connection, we examine the relationship between pill access and the age at first marriage for college women by exploiting the substantial cross-state variation in the timing of the enactment of laws giving minors access to birth control services without parental consent (see table 2). In particular, we examine the impact of state laws regarding birth control access for minors on the likelihood of getting married before age 23, for college-educated women born in the United States from 1935 to 1957. Because major changes in access to abortion also affected cohorts of women entering college in the early 1970s (abortion bans were repealed in five states in 
1970 and everywhere in 1973 with Roe $v$. Wade) and could alter marriage and career decisions similarly to improved pill access, we also include controls for abortion reform.

We use a standard differences-in-differences specification that includes controls for both state of birth and year of birth fixed effects. Our basic estimating equation includes dummy variables to account for state laws regarding birth control and abortion access, in each woman's state of birth, when she was 18 years, around the age at college entrance. ${ }^{42}$ We use the 1 percent sample of the 1980 Census of Population from the Integrated Public Use Microdata Series (IPUMS). ${ }^{43}$

The basic specification we estimate has the form

$$
M_{i s y}=\alpha_{s}+\delta_{y}+X_{i s y} \beta+P_{s y} \gamma+A_{s y} \pi+\epsilon_{i s y},
$$

where $i$ indexes individuals; $s$ indexes state of birth; $y$ indexes year of birth; the dependent variable $M_{i s y}$ is a dummy variable equal to one if individual $i$ was married before age 23; $X_{i s y}$ contains demographic controls (race dummies); $P_{s y}$ is a dummy variable equal to one if $i$ 's state of birth had a nonrestrictive birth control law for minors at the time $i$ was 18 years old; $A_{s y}$ is a dummy variable equal to one if abortion was legal in $i$ 's state of birth at the time $i$ was 18 years old; the $\alpha_{s}$ are state of birth dummies; and the $\delta_{y}$ are year of birth dummies.

Because we are concerned with the possible endogeneity of birth control access laws to state trends in feminist views and attitudes toward women's careers, we examine the robustness of our results to including controls for state of birth linear time trends. The earliest states providing minors access to birth control without parental consent were California and Georgia in 1968; Mississippi in 1969; Arkansas in 1970; and Colorado, District of Columbia, Illinois, Michigan, New Hampshire, New York, Oregon, and Tennessee in 1971 (see table 2). The wide array of states suggests that idiosyncratic factors affected the passage of mature minor and family planning laws and not, for example, the strength of the women's movement in the state.

Table 4 presents our estimates of the effect of various state laws on the age at first marriage for cohorts of college women born before and

\footnotetext{
${ }^{42}$ Ideally, we would like to know the legal environment concerning birth control and abortion for each individual in her state of residence as a teenager and in college. The census provides information on state of birth and current residence only. Since the vast majority of college-going women reside in their state of birth at 18 and go to college in their state of birth, measures of the legal environment in the state of birth should be a reasonable proxy for the actual laws affecting these women.

${ }^{43}$ We cannot extend the analysis to examine the impact of pill access laws on age at first marriage for cohorts born after 1957 since the 1990 census does not include information on the age at first marriage and more recent Current Population Survey fertility supplements do not include state of birth information.
} 
after the diffusion of the pill to single women. ${ }^{44}$ The estimates in column 1 indicate that the adoption of a nonrestrictive birth control law for minors was associated with a modest (but statistically significant) twopercentage-point decline in the probability that a college graduate women was married before age 23. The estimates in column 2 show roughly similar effects of both access to birth control and legalization of abortion. The estimates in column 3 indicate that the impact of access to birth control is robust to (and even modestly increased by) including controls for state of birth linear trends, although the same is not the case for the abortion law variable.

Since an indicator variable for state legalization of abortion is likely to be a crude indicator of access to abortion, we also explore the impacts of a continuous measure: the average abortion rate (abortions/live births) in an individual's state of birth when the individual was 18-21 years of age. ${ }^{45}$ The specification in column 4 parallels that of column 2 , with the abortion rate variable replacing the abortion legalization dummy variable.

The estimates in column 4 show a large negative and statistically significant impact of the state abortion rate on the likelihood a college woman marries by age 23 . The mean of the abortion rate variable increased from zero through the 1948 birth cohort to 0.4 for the 1957 birth cohort. Thus the abortion rate coefficient $(-0.0653)$ in column 4 implies that changes in access to abortion can explain a 2.6-percentagepoint decrease in the fraction marrying by age 23, from the pre-1949 to the 1957 birth cohorts. The inclusion of the measure of continuous access to abortion in column 4 reduces the magnitude and significance of the dummy variable measuring nonrestrictive access to birth control for minors from the specification in column 2. But column 5 shows that a substantial and statistically significant effect of access to birth control reemerges once state of birth linear time trends are included and the abortion rate effect becomes small and insignificant.

We also explore the robustness of our findings to alternative measures of state laws concerning pill access for minors. Columns 6 and 7 include two dummy variables indicating the earliest age of legal access to birth control for each state of birth and year of birth group. Pill access by age 17 has a substantial negative effect on the likelihood of being married before age 23 in models with and without state of birth trends and

\footnotetext{
${ }^{44}$ We follow the usual approach of reporting Huber-White standard errors adjusted for clustering within state/year of birth cells. Because there could be serial dependence in errors across birth cohorts but within states, we also report (in brackets) the more conservative Huber-White standard errors with clustering at the more aggregate state of birth level following the suggestions of Bertrand, Duflo, and Mullainathan (2001) and Kézdi (2001).

${ }^{45}$ This approach parallels Donohue and Levitt's (2001) use of such an abortion rate measure in analyzing the impact of legalized abortion on crime rates.
} 
TABLE 4

State Laws and the Age at First Marriage for College Women (U.S. Natives Born 1935-57) Dependent Variable: 1 = Married before Age 23

\begin{tabular}{|c|c|c|c|c|c|c|c|c|c|}
\hline & \multicolumn{7}{|c|}{ College Graduates } & \multicolumn{2}{|c|}{$\begin{array}{c}\text { Some College OR } \\
\text { More }\end{array}$} \\
\hline & (1) & (2) & (3) & (4) & (5) & (6) & (7) & (8) & (9) \\
\hline Mean of dependent variable & 41 & .41 & .41 & .41 & .41 & .41 & 41 & .53 & .53 \\
\hline $\begin{array}{l}\text { Nonrestrictive birth control } \\
\text { law at age } 18^{*}\end{array}$ & $\begin{array}{c}-.0196 \\
(.00737) \\
{[.0109]}\end{array}$ & $\begin{array}{c}-.0162 \\
(.00762) \\
{[.0105]}\end{array}$ & $\begin{array}{c}-.0207 \\
(.00920) \\
{[.00941]}\end{array}$ & $\begin{array}{c}-.00986 \\
(.00791) \\
{[.0107]}\end{array}$ & $\begin{array}{c}-.0227 \\
(.00917) \\
{[.00995]}\end{array}$ & & & $\begin{array}{c}-.0124 \\
(.00600) \\
{[.0100]}\end{array}$ & \\
\hline Pill access by age $17^{\dagger}$ & & & & & & $\begin{array}{c}-.0262 \\
(.0115) \\
{[.0163]}\end{array}$ & $\begin{array}{c}-.0324 \\
(.0131) \\
{[.0143]}\end{array}$ & & $\begin{array}{c}-.0240 \\
(.00872) \\
{[.00143]}\end{array}$ \\
\hline Pill access by ages $18-20^{\ddagger}$ & & & & & & $\begin{array}{c}-.00894 \\
(.00822) \\
{[.00922]}\end{array}$ & $\begin{array}{c}-.0126 \\
(.00821) \\
{[.00920]}\end{array}$ & & $\begin{array}{c}-.0132 \\
(.00593) \\
{[.00676]}\end{array}$ \\
\hline Legalized abortion at age $18^{\S}$ & & $\begin{array}{c}-.0236 \\
(.00992) \\
{[.0103]}\end{array}$ & $\begin{array}{c}-.0114 \\
(.00956) \\
{[.0103]}\end{array}$ & & & & & $\begin{array}{c}-.00974 \\
(.00777) \\
{[.00727]}\end{array}$ & $\begin{array}{c}-.00904 \\
(.00761) \\
{[.00705]}\end{array}$ \\
\hline
\end{tabular}


Average abortion rate at ages

$18-21$

Race dummies

State of birth dummies

Year of birth dummies

State-specific linear trend

Observations

$R^{2}$

$-.0653$

.00523

$(.0164) \quad(.0267)$

$[.0146] \quad[.0260]$

SoURCE. -1980 Census of Population, IPUMS, 1 percent sample (Ruggles and Sobek 1997).

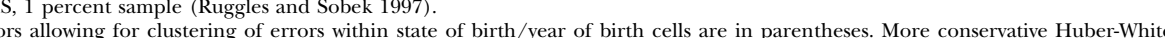
(a) years of completed schooling.

* The nonrestrictive birth control dummy variable equals one for individuals born in a state that, at the time the in allowing minors (16 years and older) to receive birth control services and devices without parental consent. See table 2

inual to one for individuals born in a state that, at the time the individual was 17 years old, had a law allowing minors 17 years and younger access to birth contro without parental consent

(n) artiest age to receive birth control without parental consent, for their birth cohort, was 18-20 yeas. Hawaii, N.Y., and Wash.) aummy equals one if abortion was legal in the individual's state of birth by the time the individual was 18 years old. In five states (Alaska, Calif., Roe v. Wade in 1973 (affecting cohorts born after 1954). On abortion laws, see Levine et al. (1996, table 1). abortion information from annual survey data conducted by the Alan Guttmacher Institute. The abortion rate is assumed to be zero in each state prior to legalization. 
controls for access to abortion. ${ }^{46}$ And column 8 shows modestly attenuated results for the impact of a nonrestrictive birth control law at age 18 when the sample is expanded to include all women with a year or more of college (to address the possible endogeneity of college graduation decisions to pill access). Column 9 shows substantial negative effects of pill access by age 17 and from ages 18 to 20 on the share married by 23 when the sample contains all with at least some college.

Using the column 3 results, we find that nonrestrictive laws decreased the fraction married by age 23 by 0.021 . Using the column 7 results, we find that pill access by age 17 decreased the fraction married before 23 by 0.032 . Relative to the total change from the 1940s cohorts to the early 1950s cohorts, these point estimates imply that improved pill access for minors in a state generated a change of 24-37 percent of the 8.7percentage-point total decline. ${ }^{47}$ Our estimates of the effect of state laws on the age at first marriage may be attenuated, relative to the overall impact of pill access, given our crude measure of state laws. Furthermore, some of the effects of increased accessibility of the pill after the late 1960s are likely to be absorbed by the full set of year of birth dummies included in all our specifications.

Further robustness checks reveal the following. Results similar to those in table 4 are found when the dependent variable is an indicator for marriage before age 22. A parallel analysis to table 4, for a sample restricted to white college graduates, yields qualitatively similar findings but with modestly larger effects of pill access laws.

\section{Career and Marital Status Outcomes: Aggregate Cohort Analysis}

We next formally examine the extent to which changes in long-run career and marital status outcomes (from ages 30 to 49 years) for successive cohorts of U.S. college women are related to their pill access when they were young (under 21 years), unmarried college students. Ideally, we would like to analyze a longitudinal data set that tracked college women in successive cohorts and had information on their pill access and usage, their educational investments, and their life cycle career attainment and marital status. Given the absence of such ideal data, we rely on a cruder aggregate cohort analysis based on data from the 1970, 1980, and 1990 U.S. population censuses to relate snapshot

\footnotetext{
${ }^{46}$ The estimated impact of the pill access age variables on the age at first marriage is similar in models that control for either the abortion legalization dummy or the continuous average abortion rate variable.

${ }^{47}$ The share of U.S.-born female college graduates married before age 23 declined from 47.0 percent for those born from 1940 to 1949 to 38.3 percent for those born from 1950 to 1954 (1980 IPUMS). See also fig. 5, which uses Current Population Survey data and is not restricted to the native-born.
} 
measures of career and marital status outcomes for single year of birth cohorts of college women to their access to the pill and abortion when young.

The unit of observation in our empirical analysis is an age/year cell (or, equivalently, a year of birth/calendar year cell). We examine 20 age groups (ages 30-49) across the three census years (1970, 1980, and 1990), yielding 60 observations (derived from 133,126 micro observations in the three censuses) and covering the 1921-60 birth cohorts of U.S.-born college graduate women.

Our basic estimating equation has the form

$$
Y_{a t}=\alpha_{a}+\delta_{t}+X_{a t} \beta+P_{a t} \gamma+A_{a t} \pi+\epsilon_{a t}
$$

where $a$ indexes age and $t$ census year; the dependent variable $Y_{a t}$ measures the share of age group $a$ (or, equivalently, of year of birth cohort $y$, where $a+y=t$ ) experiencing a particular career or marital status outcome in year $t ; X_{a t}$ contains controls for race; $P_{a t}$ is a measure of access to or usage of birth control for cohort members as young women; $A_{a t}$ is a measure of access to or usage of abortion for cohort members as young women; the $\alpha_{a}$ are a full set of age dummies; and the $\delta_{t}$ are a full set of census year dummies.

The basic idea behind the specification is to observe successive cohorts at the same age to examine whether between-cohort changes in career and marital status outcomes are related to between-cohort changes in access to the pill and abortion for young single women, controlling for preexisting trends in these outcomes across cohorts. The specification is equivalent to controlling for a set of unrestricted single year of age (life cycle) effects, a preexisting linear time trend in outcomes across birth cohorts, and a discrete aggregate jump (time effect) for 1990.

We relate the career and marital status outcomes of a birth cohort to their actual pill usage (proxied by the fraction of college women in a cohort taking the pill before age 21 among those with no births before age 23, as in fig. 1) and their pill access (proxied by the fraction in a cohort born in a state with a nonrestrictive birth control access law when they were younger than 21 years). We include similar controls for the abortion rate (for all women rather than college women) when each cohort was in college (aged 18-21 years) and the abortion legalization environment they faced at college entrance (at age 18).

Columns 1 and 2 of table 5 examine how pill and abortion access affected the fraction of college women employed in professional occupations (excluding nursing and noncollege teaching). The estimates in column 1 show that the pill usage and abortion rate measures have similar strong positive effects on the share of college women employed 
TABLE 5

Impact of Pill Acgess and Abortion legalization on Career and Marital Status for College Women, 30-49 Years Old (U.S. Natives Born 1921-60)

\begin{tabular}{|c|c|c|c|c|c|c|c|c|c|}
\hline & \multicolumn{2}{|c|}{$\begin{array}{c}\text { Professional } \\
\text { Occupation, Ex- } \\
\text { CLUding TeACH- } \\
\text { ERS, NuRSES } \\
\end{array}$} & \multicolumn{2}{|c|}{ LAWYER, DOCTOR } & \multirow{2}{*}{$\begin{array}{c}\text { NeVER } \\
\text { MARRIED } \\
(5)\end{array}$} & \multirow{2}{*}{$\begin{array}{c}\text { CuRRENTLY } \\
\text { MarRIED } \\
(6)\end{array}$} & \multirow{2}{*}{$\begin{array}{c}\text { CuRRENTLY } \\
\text { DivorCED } \\
(7)\end{array}$} & \multicolumn{2}{|c|}{$\begin{array}{c}\text { CURRENTLY DI- } \\
\text { VORCED/EVER } \\
\text { MARRIED }\end{array}$} \\
\hline & (1) & (2) & (3) & (4) & & & & (8) & (9) \\
\hline Mean of dependent variable & .127 & 127 & .0141 & .0141 & .126 & .749 & .0916 & .104 & .104 \\
\hline Fraction $\mathrm{l}$ & $\begin{array}{l}.0480 \\
(.0275)\end{array}$ & & $\begin{array}{l}.0352 \\
(.00539)\end{array}$ & & & & & $\begin{array}{r}-.0325 \\
(.0257)\end{array}$ & \\
\hline $\begin{array}{l}\text { Fraction with pill access law before } \\
\text { age } 21^{\dagger}\end{array}$ & & $\begin{array}{l}.00410 \\
(.0142)\end{array}$ & & $\begin{array}{l}.0159 \\
(.00353)\end{array}$ & $\begin{array}{l}.0608 \\
(.0189)\end{array}$ & $\begin{array}{c}-.00813 \\
(.0230)\end{array}$ & $\begin{array}{l}-.0596 \\
(.0107)\end{array}$ & & $\begin{array}{r}-.0558 \\
(.0121)\end{array}$ \\
\hline $\begin{array}{l}\text { Average abortion rate from ages } \\
18 \text { to } 21^{\ddagger}\end{array}$ & $\begin{array}{l}.0457 \\
(.0230)\end{array}$ & & $\begin{array}{l}.0306 \\
(.00451)\end{array}$ & & & & & $\begin{array}{l}-.149 \\
(.0215)\end{array}$ & \\
\hline $\begin{array}{l}\text { Fraction with legalized abortion at } \\
\text { age } 18^{\S}\end{array}$ & & $\begin{array}{l}.0236 \\
(.0146)\end{array}$ & & $\begin{array}{l}.00255 \\
(.00362)\end{array}$ & $\begin{array}{l}.0431 \\
(.0194)\end{array}$ & $\begin{array}{l}-.0299 \\
(.0236)\end{array}$ & $\begin{array}{c}-.0127 \\
(.0110)\end{array}$ & & $\begin{array}{r}-.0135 \\
(.0124)\end{array}$ \\
\hline
\end{tabular}




\begin{tabular}{lccccccccc} 
Census year $=1980$ & .0153 & .0202 & .00136 & .00361 & -.00305 & -.0521 & .0561 & .0622 & .0627 \\
& $(.00531)$ & $(.00493)$ & $(.00104)$ & $(.00123)$ & $(.00655)$ & $(.00799)$ & $(.00371)$ & $(.00498)$ & $(.00420)$ \\
Census year $=1990$ & .0381 & .0496 & .00568 & .0104 & -.0118 & -.0847 & .105 & .112 & .116 \\
& $(.00904)$ & $(.00773)$ & $(.00177)$ & $(.00192)$ & $(.0103)$ & $(.0125)$ & $(.00582)$ & $(.00848)$ & $(.00660)$ \\
Age dummies & yes & yes & yes & yes & yes & yes & yes & yes & yes \\
Observations & 60 & 60 & 60 & 60 & 60 & 60 & 60 & 60 & 60 \\
$R^{2}$ & .864 & .859 & .962 & .936 & .924 & .886 & .968 & .959 & .965 \\
\hline
\end{tabular}

SourCE. -1970, 1980, and 1990 U.S. Census of Population, IPUMS, 1 percent samples (Ruggles and Sobek 1997).

NotE. - The unit of observation in all regressions is a year/age (year/year of birth) cell. Each regression covers three years (1970, 1980, and 1990) and includes 20 single vear of age groups (from 30 to 49 years). All regressions include controls for fraction African-American and "other races." Standard errors are in parentheses. The dependent variables are year/age group means for U.S.born college graduate women (those with 16 or more years of schooling). The dependent variable in cols. 1 and 2 is the fraction currently employed in professional occupations extluding noncolege teachers and hose in heallh assessment and treating occupations (e.g., nurses, dieticians, therapists, and physicians assistants). The dependent variable in cols. 3 and 4 is the fraction employed in legal professions (lawyers and judges) and health-diagnosing professions (physicians, veterinarians, and dentists). The dependent variable in cols. 7 and 8 is the fraction of those ever married who are currently divorced.

births before age 23. Source: See fig. 1.

Donohue and Levitt (2001)

Fraction for whom abortion was legal in state of birth by the time individual was 18 years old. 
in nontraditional professional occupations from ages 30 to 49 years. ${ }^{48}$ The estimates suggest that the growth in pill usage, from nonexistent for the pre-1940 birth cohorts to 0.35 by birth cohorts born in the mid $1950 \mathrm{~s}$, accounts for a 1.7-percentage-point $(0.048 \times 0.35)$ increase in the share of women working in professional occupations across these cohorts out of an overall increase of five percentage points for these age groups from 1970 to 1990 . The implied effect of changes in the abortion rate (from zero in pre-1940s cohorts to 0.4 by the late $1940 \mathrm{~s}$ cohorts) is about the same. The estimates in column 2, however, show an insignificant impact of the pill access proxy and a marginally significant impact of abortion legalization status on the share of women in professional occupations. But, as we emphasized before, we expect the pill to have been most effective in enabling women to engage in professions requiring substantial up-front investments.

Thus in columns 3 and 4 we examine the impact of pill and abortion access on the fraction of college women employed as lawyers and doctors (physicians, veterinarians, and dentists), all professional careers requiring long-term investments. Both measures of pill access have strong positive and statistically significant impacts on the movement of college women into these professions. Improved pill access from the pre-1940 to the mid 1950s birth cohorts, according to columns 3 and 4, can explain an increase in the share of college women as lawyers and doctors of $1.2(0.0352 \times 0.35)$ to $1.6(0.0159 \times 0.98)$ percentage points as compared with an overall increase of 1.7 percentage points from 1970 to 1990. The impact of abortion is less robust to the choice of abortion access measure. ${ }^{49}$

With respect to marital status outcomes, the estimates in columns 5-7 indicate that access to birth control is associated with an increase in the share never married (consistent with the results in table 4 on the age at first marriage using within-state variation in pill access laws). Access has a trivial impact on the share currently married but a substantial negative effect on the share currently divorced. Legalization of abortion has similar (but modestly smaller) positive effects on the share never married and a smaller (and less significant) negative impact on the share currently divorced..$^{50}$

${ }^{48}$ We report conventional standard errors in table 5, which are almost identical to HuberWhite robust standard errors clustered by year of birth cohorts to account for multiple (two) observations for birth cohorts born from 1931 to 1950.

${ }^{49}$ We also find in analogous (unreported) specifications that increased pill access is associated with a lower share of college women employed in nursing and (noncollege) teaching occupations and a higher share with graduate or professional training (at least one year of postcollege education).

${ }^{50}$ Specifications analogous to those of cols. 5-7, with pill and abortion access proxied by (the arguably more endogenous) actual pill usage and abortion rate variables, generate qualitatively similar results on current marital outcomes but with somewhat larger estimated magnitudes. 
The negative effect of pill access on divorce is not caused by an increase in the share who never married (see cols. 8 and 9). Rather, improved pill access and greater pill usage for young women are negatively related to divorce even among the ever married. Although the overall divorce rate skyrocketed from 1970 to 1990, the rise in divorce actually slowed as birth cohorts with greater pill access moved into the 30-49-year age group. ${ }^{51}$ The effect suggests that pill access improved the quality of marriage matches by increasing the age at first marriage. Individuals marrying later have a better sense of their preferences, and the effect outweighed the possible spur to divorce from improved careers and lower birth rates from the pill. ${ }^{52}$

We have explored the robustness of the results presented in table 5 along several dimensions. The impact of pill usage is invariant to various measures, for example, using the figure 2 data on first family planning visits before age 21 rather than those given by the fraction taking the pill before age 21. The findings are also not much affected by using measures for pill access at different ages (e.g., age 17 or younger and ages 18-20) and from looking at a narrower range of cohorts (e.g., women aged 35-44 years for the birth cohorts from 1926 to 1955). Finally, the qualitative findings for the outcomes in table 5 are similar if the sample is expanded to include women with any college and all women regardless of education to account for the possible dependence of college graduation on pill and abortion access.

\section{The Case for the Power of the Pill}

We have built a case for the power of the pill based on the timing of changes in pill access, career change, and the age at first marriage, and we have estimated formal econometric relationships exploiting crossstate and cross-cohort variation.

Despite FDA approval of the pill in 1960 for contraceptive use and its rapid diffusion among married women, young, unmarried women did not greatly increase pill usage until the late 1960s to early 1970s.

${ }^{51}$ The estimates in col. 8 indicate that improved access to abortion, as proxied by the actual abortion rate from ages 18 to 21 , is associated with a large reduction in divorce. But the impact of abortion access on reducing divorce is much smaller (and not statistically significant) in specifications using the (arguably more exogenous) abortion legalization variable as shown in cols. 7 and 9 .

${ }^{52}$ Michael (1988) presents an annual time-series analysis of the U.S. divorce rate from 1920 to 1974 . He finds that an index of the overall diffusion of new contraceptive technologies (pill and intrauterine devices) helps explain the acceleration in growth of the U.S. divorce rate in the 1960s. This contrasts with our finding that greater pill access is associated with a reduction in the growth of divorce across successive cohorts of college women. Our approach differs by examining individual year of birth cohorts, controlling for aggregate year effects, and looking at the impact of pill access for young, single college women. 
The primary reason was legal barriers. Beginning in the late 1960s, states lowered the age of majority and increased the rights of minors. These legal changes were largely independent of demands for contraceptive services and were generated by an enhanced awareness, due in part to the Vietnam War, that young people had earned greater rights. Many physicians, to be sure, had not been in compliance before the changes, but university health services generally did comply. The timing of greater pill use among cohorts of college graduate women coincided with the increase in the age at first marriage and the initial increase of female first-year students in professional programs, such as law, medicine, dentistry, and business administration. More lenient laws led to a greater use of oral contraceptives and directly produced an increase in the age at first marriage and also led to an increase in the fraction of women entering professional school and ending up in professional careers.

\section{Alternative Explanations}

We have offered a supply-driven explanation for the change in the career plans of young college graduate women. A related and complementary supply-side explanation is abortion reform. We showed, in table 4, that a dummy variable for the five states that underwent early abortion reform and a variable measuring abortion rates in a woman's state of birth when she was 18-21 years old were negatively related to the age at first marriage, but the variables for the nonrestrictive birth control states were more robust to the inclusion of state-specific trends. ${ }^{53}$ The estimates in table 5 indicate that measures of access to both birth control and abortion help explain changes among successive cohorts of college women in the share employed in professional careers when in their thirties and forties.

The case for the greater importance of the pill is mainly that oral contraceptives had a far wider impact than abortion. College women did not depend on abortion, as they did on the pill, for safe, reliable, effective, convenient, and painless contraception. Yet, even though the fraction of women who ever took the pill vastly exceeded that who ever had an abortion (by more than eight to one for nonvirgins), the rate of abortion use among young women was high by 1976 and moderate even in 1971 (see table 6). Its effect must have served to reinforce the pill's impact.

Another supply-side explanation concerns changes in the "sex ratio," the ratio of men to women of marriageable age (Grossbard-Shechtman 1993). The sex ratio may affect female marriage rates and their incentives to invest in careers (Becker 1974). Because women typically marry

${ }^{53}$ Two populous states (California and New York), it should be noted, are in both groups. 
TABLE 6

Abortion and Pill Use among 18- and 19-Year-Old Women, 1971 and 1976

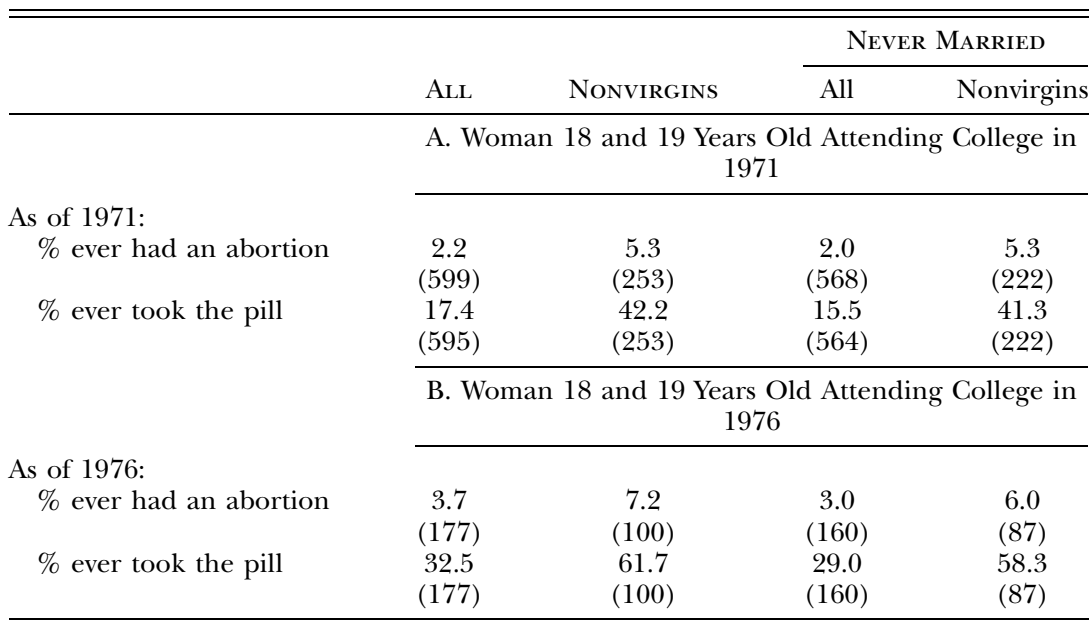

SourCE. - National Survey of Young Women, 1971; National Survey of Adolescent Female Sexual Behavior. NoTE.-Numbers of observations are in parentheses.

men two to three years older, women born early in the baby boom (the mid to late 1940s) should have faced poorer marriage market conditions than those born in the 1950s and 1960s. Yet marriage rates for college women did not increase until cohorts born from the late 1940s to early 1950s and did not decrease for later ones facing more favorable sex ratios. ${ }^{54}$

The most difficult supply-side explanation to assess is the resurgence of feminism in America. Feminism empowered young women to see themselves as the equal of their male peers, and it was complementary to the pill by increasing the number of young women who believed they could aim for the top.

Demand-side explanations involving a change in the relative demand for women by employers and educational institutions can also be offered. They include sex discrimination legislation and the ending of Vietnam-era draft deferments.

Although the Civil Rights Act of 1964 covered discrimination by "sex," the Equal Employment Opportunity Commission (EEOC) set up to investigate charges did little about sex discrimination until the early 1970s. ${ }^{55}$ Affirmative action in the form of Executive Order 11246 was amended in 1967 by Executive Order 11375 to cover women, but it took

\footnotetext{
${ }^{54}$ An interaction between marriage market effects, driven by sex ratio changes, and the pill may help account for this anomaly (Heer and Grossbard-Shechtman 1981).

${ }^{55}$ The National Organization for Women was formed in 1966 to pressure the EEOC to consider discrimination by sex. Sex discrimination complaints rose from about 3,150 in 1970 to 18,150 in 1973, peaking at 29,450 in 1976 (Goldin 1990, fig. 7.1).
} 
many years to be put into effect (Freeman 1975). Title IX, guaranteeing women equal access to federally funded colleges and universities, was passed in 1972, but its guidelines were not formulated until 1975. Antidiscrimination legislation had effects complementary to that of the pill, but its timing appears to have been a bit too late for it to have been the spark.

Draft deferments for graduate and some professional students ended in 1967, but those for various health professionals continued until the draft was abolished in 1973 (Singer 1989; Angrist and Krueger 1992). One would have expected a draft-induced surge in male applicants to medical and dental schools through 1973 that would have squeezed out female applicants. But the upsurge in female medical and dental students began around 1970. ${ }^{56}$

An additional problem with the demand-side explanations mentioned is that they cannot account for other related changes. The increased age at first marriage could have stemmed from more career investment, but the rise in sexual activity among single women, beginning in 1970 , would appear entirely unrelated.

\section{Summary: A Collage of Evidence on Career, Marriage, and the Pill}

We have presented a collage of evidence for the impact of the pill on young women's career decisions and on marriage rates in the 1970s. The direct effect of the pill decreased the cost to women of remaining unmarried while investing in a professional career. The pill further reduced the cost of career investment for women by serving to increase the age at first marriage for a large fraction of all young people. The power of the pill in affecting women's careers was magnified by its impact on the age at first marriage.

But not all increases in the age at first marriage and decreases in fertility have involved genuine social change for women. Marriage and fertility rates decreased at other times in U.S. demographic history but did not lead to vast increases in the fraction of women in professional occupations. Similarly, Japanese women experienced a substantial decline in fertility and an increase in the age at first marriage from the early 1970s. Yet women's economic status in Japan has seen little change, and, until 1999, oral contraceptives were not legally available.

The pill is not necessary for demographic change. But a virtually foolproof, easy-to-use, and female-controlled contraceptive having low

\footnotetext{
${ }^{56}$ The same exemption did not apply to law students. The draft may have increased the acceptance rate for women applying to law school, but we have not been able to obtain data on law school applications and acceptances.
} 
health risks, little pain, and few annoyances does appear to have been important in promoting real change in the economic status of women (Birdsall and Chester 1987). Moreover, women in the United States were well positioned to take advantage of the pill's side benefit. By the time the pill was available to unmarried women, about 28 percent were graduating from four-year institutions of higher education. ${ }^{57}$ In most other rich countries, the fraction of young women capable of continuing to professional schools was small since college graduation rates were low compared with those of the United States.

The most persuasive evidence for a role of the pill is that its initial diffusion among single women coincided with, and is analytically related to, the increase in the age at first marriage and the increase in women in professional degree programs. Other factors were involved in these changes, to be sure. No great social movement is caused by a single factor.

Appendix

TABLE A1

Data Sets Containing Information on Contraceptive Use, 1955-87

\begin{tabular}{lc}
\hline \hline Data Set, Year(s), and Observations & Sample Characteristics \\
\hline National Fertility Surveys (NFS): & Currently married women, married prior \\
$1965(N=5,617), 1970$ & to age 25; retrospective information on \\
$(N=6,752)$, and 1975 followup & contraceptive use was taken only for \\
periods in which respondent was & married \\
& Young women, never married and ever \\
National Survey of Young Women & married, 15-19 years old; contains cur- \\
$($ NSYW71): $1971(N=4,611)$ & rent state of residence \\
National Survey of Adolescent Fe- & Young women, never married and ever \\
male Sexual Behavior (NSAF76): & married, 15-19 years old; does not con- \\
$1976(N=2,193)$ & tain current state of residence \\
National Health Interview Survey & Women born 1929-69 (aged 18-67); con- \\
$($ NHIS): $1987(N=12,747)$ & tains information on age at first pill \\
& use, but none on age at first marriage \\
National Survey of Family Growth, & Women 15-44 years old; contains infor- \\
Cycle III $($ NSFG): 1982 & mation on age at first family planning \\
$(N=7,969)$ & visit and age at first marriage \\
\hline
\end{tabular}

${ }^{57}$ See Goldin (1997, app. table 2.1) for data based on the Current Population Survey, series P-20. The fraction graduating from college or university is about 28 percent for cohorts born in the late 1940s. 


\section{References}

Akerlof, George A.; Yellen, Janet L.; and Katz, Michael L. "An Analysis of Outof-Wedlock Childbearing in the United States." Q.J.E. 111 (May 1996): 277-317.

Angrist, Joshua D., and Krueger, Alan B. "Estimating the Payoff to Schooling Using the Vietnam-Era Draft Lottery." Working Paper no. 4067. Cambridge, Mass.: NBER, May 1992.

Asbell, Bernard. The Pill: A Biography of the Drug That Changed the World. New York: Random House, 1995.

Bailey, Beth. "Prescribing the Pill: Politics, Culture, and the Sexual Revolution in America's Heartland." J. Soc. Hist. 30 (Summer 1997): 827-56.

Barbato, Louis. "Study of the Prescription and Dispensing of Contraceptive Medications at Institutions of Higher Education." J. American Coll. Health Assoc. 19 (June 1971): 303-6.

Barbato, Louis, et al. "Dispensing of Birth Control Information, Devices and Medications in College Health Services: A Panel Discussion.” J. American Coll. Health Assoc. 16 (February 1968): 233-35.

Becker, Gary S. "A Theory of Marriage." In Economics of the Family: Marriage, Children, and Human Capital, edited by Theodore W. Schultz. Chicago: Univ. Chicago Press (for NBER), 1974.

Bergstrom, Theodore C., and Bagnoli Mark. "Courtship as a Waiting Game." J.P.E. 101 (February 1993): 185-202.

Bertrand, Marianne; Duflo, Esther; and Mullainathan, Sendhil. "How Much Should We Trust Differences-in-Differences Estimates?" Manuscript. Cambridge: Massachusetts Inst. Tech., July 2001.

Birdsall, Nancy, and Chester, Lauren A. "Contraception and the Status of Women: What Is the Link?” Family Planning Perspectives 19 (January-February 1987): 14-18.

Black, Sandra E., and Juhn, Chinhui. "The Rise of Female Professionals: Are Women Responding to Skill Demand?” A.E.R. Papers and Proc. 90 (May 2000): 450-55.

Cole, Stephen. "Sex Discrimination and Admission to Medical School, 19291984." American J. Sociology 92 (November 1986): 549-67.

Dienes, C. Thomas. Law, Politics, and Birth Control. Urbana: Univ. Illinois Press, 1972.

Donohue, John J., III, and Levitt, Steven D. "The Impact of Legalized Abortion on Crime." Q.J.E. 116 (May 2001): 379-420.

Freeman, Jo. The Politics of Women's Liberation: A Case Study of an Emerging Social Movement and Its Relation to the Policy Process. New York: Longman, 1975.

Goldin, Claudia. Understanding the Gender Gap: An Economic History of American Women. New York: Oxford Univ. Press, 1990.

- "Career and Family: College Women Look to the Past." In Gender and Family Issues in the Workplace, edited by Francine Blau and Ronald G. Ehrenberg. New York: Sage Found., 1997.

Goldin, Claudia, and Katz, Lawrence F. "The Power of the Pill: Oral Contraceptives and Women's Career and Marriage Decisions." Working Paper no. 7527. Cambridge, Mass.: NBER, February 2000.

Grossbard-Shechtman, Shoshana. On the Economics of Marriage: A Theory of Marriage, Labor, and Divorce. Boulder, Colo.: Westview Press, 1993.

Heer, David M., and Grossbard-Shechtman, Amyra. "The Impact of the Female Marriage Squeeze and the Contraceptive Revolution on Sex Roles and the 
Women's Liberation Movement in the United States, 1960 to 1975.” J. Marriage and Family 43 (February 1981): 49-65

Hollis, Gloria, and Lashman, Karen. "Family Planning Services in U.S. Colleges and Universities." Family Planning Perspectives 6 (Summer 1974): 173-75.

Inter-university Consortium for Political and Social Research. National Survey of Adolescent Female Sexual Behavior, 1976 (ICPSR 8043). Principal investigators: John F. Kantner and Melvin Zelnick. Ann Arbor, Mich.: Inter-university Consortium Polit. and Soc. Res., 1982.

. National Survey of Family Growth, Cycle III, 1982 (ICPSR 8328). Ann Arbor, Mich.: Inter-university Consortium Polit. and Soc. Res., 1985.

- National Health Interview Survey, 1987: Cancer Risk Factor Supplement, Epidemiology Study (ICPSR 9341). Ann Arbor, Mich.: Inter-university Consortium Polit. and Soc. Res., 1990.

Kantner, John F., and Zelnik, Melvin. "Sexual and Contraceptive Experience of Young Unmarried Women in the United States, 1976 and 1971." Family Planning Perspectives 9 (March-April 1977): 55-71.

Kelly, Gary F. Sexuality Today: The Human Perspective. 6th ed. New York: McGrawHill, 1998.

Kézdi, Gábor. "Robust Standard Error Estimation in Fixed-Effects Panel Models." Manuscript. Ann Arbor: Univ. Michigan, July 2001.

Levine, Phillip B.; Staiger, Douglas; Kane, Thomas J.; and Zimmerman, David J. "Roe v. Wade and American Fertility." Working Paper no. 5615. Cambridge, Mass.: NBER, June 1996.

Michael, Robert T. "Why Did the U.S. Divorce Rate Double within a Decade?" In Research in Population Economics, vol. 6, edited by T. Paul Schultz. Greenwich, Conn.: JAI, 1988.

Ohio State University. National Longitudinal Survey of Women 14-24 in 1968. CDROM. Columbus: Ohio State Univ., Center Human Resource Res., 1968-1991.

“Oral Contraceptives: The Liberator." Economist (December 31, 1999), p. 102.

Paul, Eve W.; Pilpel, Harriet F.; and Wechsler, Nancy F. "Pregnancy, Teenagers and the Law, 1974." Family Planning Perspectives 6 (Summer 1974): 142-47.

"The Pill on Campus." Wall Street J. (January 19, 1970).

Pilpel, Harriet F., and Wechsler, Nancy F. "Birth Control, Teenagers and the Law." Family Planning Perspectives 1 (Spring 1969): 29-36.

Ruggles, Steven, and Sobek, Matthew. Integrated Public Use Microdata Series, IPUMS98 Version 2.0. Minneapolis: Univ. Minnesota, Dept. Hist., Soc. Hist. Res. Lab., 1997. http://www.hist.umn.edu/ipums/.

Sarrel, Philip M., and Sarrel, Lorna J. "Birth Control Services and Sex Counseling at Yale." Family Planning Perspectives 3 (July 1971): 33-36.

Scrimshaw, Susan C. M. "Women and the Pill: From Panacea to Catalyst." Family Planning Perspectives 13 (November-December 1981): 254-62.

Singer, Allen. "The Effect of the Vietnam War on Numbers of Medical School Applicants." Academic Medicine 64 (October 1989): 567-73.

U.S. Department of Commerce. Statistical Abstract of the United States: 1999. Washington: Government Printing Off., 1999.

U.S. Department of Education. Digest of Education Statistics. Washington: Government Printing Off., 1997, 1998.

U.S. Department of Health, Education, and Welfare. Family Planning, Contraception, and Voluntary Sterilization: An Analysis of Laws and Policies in the United States, Each State and Jurisdiction (as of September 1971). Washington: Government Printing Off., 1974.

- Family Planning, Contraception, and Voluntary Sterilization: An Analysis of 
Laws and Policies in the United States, Each State and Jurisdiction (as of October 1, 1976 with 1978 addenda). Washington: Government Printing Off., 1978.

U.S. Department of Labor. Bureau of Labor Statistics. Employment and Earnings. Vol. 48. Washington: Bur. Labor Statis., January 2001.

Watkins, Elizabeth Siegel. On the Pill: A Social History of Oral Contraceptives, 1950-1970. Baltimore: Johns Hopkins Univ. Press, 1998.

Westoff, Charles F., and Potvin, Raymond H. College Women and Fertility Values. Princeton, N.J.: Princeton Univ. Press, 1967.

Westoff, Charles F., and Ryder, Norman B. The Contraceptive Revolution. Princeton, N.J.: Princeton Univ. Press, 1977.

Zelnik, Melvin, and Kantner, John F. "Sexual Experience of Young Unmarried Women in the United States." Family Planning Perspectives 4 (October 1972): 9-18.

"1971 U.S. National Survey of Young Women.” Machine-readable data file. In Data Archive on Adolescent Pregnancy and Pregnancy Prevention. Los Altos, Calif.: Sociometrics Corp., 1989. http://www.socio.com. 